\title{
Ownership and COVID-19 in care homes for older people: A living systematic review of outbreaks, infections, and mortalities
}

Anders Malthe Bach-Mortensen (0000-0001-7804-7958) a , Ben Verboom (0000-0003-3693-3833) a, Ani Movsisyan (0000-0003-0258-8912) b, Michelle Degli Esposti (0000-0002-0068-5754) a

a University of Oxford, Department of Social Policy and Intervention; Barnett House, 32 Wellington Square; Oxford; UK

b Institute for Medical Information Processing, Biometry and Epidemiology, LMU Munich, Elisabeth-Winterhalter Weg 6, 81377 Munich, Germany

Correspondence to Anders Malthe Bach-Mortensen (anders.bach-mortensen@spi.ox.ac.uk) 


\begin{abstract}
Background: The adult social care sector is increasingly outsourced to for-profit providers, who constitute the largest provider of care homes in many developed countries. During the COVID-19 pandemic, for-profit providers have been accused of failing their residents by prioritising profits over care, prevention, and caution, which has been reported to result in a higher prevalence of COVID-19 infections and deaths in for-profit care homes. Although many of these reports are anecdotal or based on news reports, there is a growing body of academic research investigating ownership variation across COVID-19 outcomes, which has not been systematically appraised and synthesised.
\end{abstract}

Objectives: To identify, appraise, and synthesise the available research on ownership variation in COVID-19 outcomes (outbreaks, infections, deaths, shortage of personal protective equipment (PPE) and staff) across for-profit, public, and non-profit care homes for older people, and to update our findings as new research becomes available.

Design: Living systematic review.

Methods: This review was prospectively registered with Prospero (CRD42020218673). We searched 17 databases and performed forward and backward citation tracking of all included studies. Search results were screened and reviewed in duplicate. Risk of bias (RoB) was assessed in duplicate according to the COSMOS-E guidance. Data was extracted by ABM and independently validated. The results were synthesised by country, RoB, and model adjustments, and visualised using harvest plots.

Results: Twenty-nine studies across five countries were included, with $75 \%$ of included studies conducted in the Unites States. For-profit ownership was not consistently associated with a higher probability of a COVID-19 outbreak. However, there was compelling evidence of worse COVID-19 outcomes following an outbreak, with for-profit care homes having higher rates of accumulative infections and deaths. For-profit providers were also associated with shortages in PPE, which may have contributed to the higher incidence of infections and deaths in the early stages of the pandemic. Chain affiliation was often correlated with an increased risk of outbreak but was usually not reported to be associated with higher rates of deaths and infections.

Conclusion: For-profit ownership was a consistent risk factor for higher cumulative COVID-19 infections and deaths in the first wave of the pandemic. Thus, ownership and the characteristics associated with FP care home providers may present key regulatable factors that can be addressed to improve health outcomes in vulnerable populations and reduce health disparities. This review will be updated as new research becomes published, which may change the conclusion of our synthesis. 


\section{Introduction}

The COVID-19 pandemic has disproportionately affected people living in residential care, who are estimated to account for approximately half of all COVID-19 deaths in developed countries ${ }^{1-3}$. This disproportionate impact can be understood, in part, in terms of the vulnerability of people residing in care homes and a lack of early intervention and support ${ }^{4}$. However, the structural and institutional risk factors are not yet well understood. In many countries, adult social care services are delivered by a combination of for-profit, non-profit, and public providers ${ }^{5}$. It is well documented that the outsourcing of social care has significantly increased the market share of private, and in particular, for-profit care providers ${ }^{6,7}$, which has motivated a large body of research investigating the association between care home ownership and quality of care ${ }^{8}$. For example, a 2009 systematic review of 82 studies on ownership variation among nursing homes found that non-profit providers typically delivered higher quality services compared to for-profit providers ${ }^{9}$; a finding that has since been replicated ${ }^{6,7,10}$.

During the COVID-19 pandemic, some news coverage expressed concern that for-profit providers have failed their residents by prioritising profits over care, prevention, and caution ${ }^{11}$, resulting in reports of higher rates of COVID-19 infections and deaths in for-profit care homes ${ }^{12,13}$. Although many of these reports are not peer-reviewed - located, for example, in newspaper publications there is a growing body of academic research that investigates ownership variation across COVID19 outcomes, such as outbreaks, infection rates, and mortality ${ }^{14,15}$.

The COVID-19 pandemic has tested the capability of not only individual care homes, but also the commissioning system in which they operate. It is known that funding for adult social care has been characterised by years of austerity ${ }^{16}$ at the expense of staffing, quality, and support, which may have been detrimental to the ability of care homes to cope with the pandemic ${ }^{17}$. As such, the experiences of the adult social care sector during the pandemic must not be forgotten, and the growing body of research on ownership variation across COVID-19 outcomes offers an important opportunity to revisit the impact of outsourcing social care services to for-profit providers.

\section{Research Question/objectives:}

The aim of this living systematic review is to identify, appraise, and synthesise the available research on ownership variation in outbreaks and infections across for-profit, public, and non-profit care homes for older people, and to update our findings as new research becomes available. A review protocol was registered prospectively on $\mathrm{OSF}^{18}$ and on Prospero (CRD42020218673).

\section{Methods}

COVID-19 related research is published at a high frequency, and the time between submission and publication is substantially shorter than for non-COVID-19 research $^{19}$, which makes it particularly important that this rapidly growing body of evidence is critically appraised and systematically synthesised regularly. To ensure that this review will represent a recent and relevant synthesis of the available evidence on the topic, it will be conducted as a living systematic review, which is defined as "a systematic review that is continually updated, incorporating relevant new evidence as it becomes available" 20,21. Specifically, we plan to update our results every 6 months for two years after initial publication. An update will entail (1) running the below search string for the updated time period, and (2) forward and backward citation tracking of all included studies. Any studies added throughout this process will be incorporated in the review and the synthesis, results, and interpretation will be adapted accordingly. This review is conducted and reported in accordance with PRISMA guidelines ${ }^{22}$ (see supplementary material for PRISMA checklist) 


\section{Search strategy}

Before developing our search strategy, we hand-searched Google Scholar and preprint repositories for relevant articles and performed citation searches on all identified articles. This preliminary sample of includable studies were used to design our search strategy and to test its specificity. The search strategy was piloted and adjusted until all pre-identified studies were identified. The full search strategy can be found in the supplementary material. Our search string was implemented in the following databases: ABI/INFORM Global, Coronavirus Research Database, Criminology Collection International (criminal justice database and NCJRS abstracts database), International Bibliography of the Social Sciences (IBSS), Politics Collection (PAIS index, policy file index, political science database, and worldwide political science abstracts), Social Science Database, Sociology Collection (applied social science index and abstracts, sociological abstracts, and sociology database) via ProQuest. We searched Embase, Global Health, Medline, and PsycINFO via Ovid. Two authors (ABM and MDE) double-screened all search results using Rayyan and subsequently reviewed the full text versions of potentially eligible studies. To ensure that the results of this review were as up-todate as possible, we tracked all new research citing the studies included from our data base search every 2 weeks, with the latest one conducted on January $26^{\text {th }}, 2021$. These on-going forward citation searches led to the identification of 9 additional studies, most of which were published after our formal search was conducted (see PRISMA diagram for details).

\section{Inclusion criteria}

We assessed study eligibility based on four criteria. First, studies had to investigate variation in COVID-19 outbreaks, infection rates, and/or excess or COVID-19 related mortalities or outcomes related to personal protective equipment (PPE) use and availability, staff shortage, preparedness, and infection and mortality among staff and visitors. We did not exclude studies based on how the COVID-19 outcomes were operationalised (e.g. if the infections were confirmed by PCR test or by self-report, and whether the analysed outcomes were dichotomised or continuous), although these aspects were considered in our risk of bias assessments. Second, studies had to investigate variation in any of the above outcomes across ownership categories, which is conventionally operationalised as 'for-profit' (e.g. private care homes run for-profit), 'non-profit' (e.g. registered private not-for-profit care home or charities), and 'public' (e.g. municipal or local authority care home). However, 'ownership' is not consistently operationalised in the literature, and terms such as 'for-profit', 'nonprofit', 'private', 'chain affiliated', and 'public' are rarely clearly defined. Since the objective of this review is to appraise and synthesise research on ownership variation, we considered any definition or classification of ownership. However, the nuances of different ownership categorisations were considered in our synthesis and interpretation (see Table A1 in the appendix for a breakdown and description of different ownership categories). Third, studies had to employ an observational research design, including, but not limited to, cross-sectional studies, cohort studies, and secondary analyses of registry data. Both published and unpublished manuscripts (e.g., preprints and reports) were eligible for inclusion. Fourth, studies had to investigate residential care homes for older people, including, but not limited to, long-term care facilities, nursing homes, and retirement homes.

\section{Data extraction, (selection and coding)}

Descriptive information on the citation details (author, title, journal) and study characteristics (research design, analysis, sample details) were retrieved from all included articles. We also extracted detailed information on the descriptive data (e.g., country, source, and period of data coverage) and the outcome and exposure variables (e.g., definition, operationalisation, and cut-offs). All results relating to ownership variation across COVID-19 related outcomes and accompanying 
interpretations were extracted for all studies. The results were extracted by ABM and independently validated by the co-authors.

\section{Risk of bias assessment}

Risk of bias (RoB) was assessed using the COSMOS-E guidance ${ }^{23}$. We employed this guidance rather than, for example, ROBINS-I for non-randomised intervention studies, as it is specifically designed for systematically reviewing observational and correlational research. Specifically, we evaluated the following bias domains: confounding, selection bias, and information bias. In line with the consistent recommendation to avoid quantitative scoring of risk domains ${ }^{23,24}$, all RoB assessments were based on the qualitative subjective assessment of the reviewers, which were decided through discussion and in consensus. All assessments were conducted with the focus of our review (variation in COVID-19 outcomes across ownership) in mind, and the assessments may thus not represent the risk of bias across other investigated associations and outcomes. The overall RoB assessment for each study was based on the lowest assessment in any bias domain. We did not exclude studies based on the RoB assessments.

\section{Data synthesis}

Due to a high degree of heterogeneity among the included studies in terms of model specifications, operationalisation of outcomes, inconsistent ownership categorisation of the reference group, and overlapping data, we did not perform a statistical meta-analysis of the included results. This decision was made with attention to the pitfalls of employing statistical methods and assumptions designed for the analysis of very homogenous data or randomised controlled trials of interventions to observational and correlational research ${ }^{25}$. If appropriate however, we will meta-analyse the results in later versions of this living review. Our synthesis was guided by the Synthesis Without Metaanalysis (SWiM) guidelines ${ }^{26}$ and can be described as follows.

First, we narratively summarised key characteristics of the included studies, such as publication type, sample details, ownership categorisation, and data sources. Second, we assessed the risk of bias across all included studies. Third, we developed an overview of the strength of evidence for specific outcomes and model adjustments of all contributing studies. The model adjustment categories were developed according to aspects known to influence the relationship between ownership and care homes. Fourth, we constructed a harvest plot to graphically illustrate the direction of the effects across different outcomes and ownership categories with attention to the model specifications and risk of bias of contributing studies ${ }^{27}$. Harvest plots serve as a way to synthesise and describe a heterogenous body of evidence, which cannot be meaningfully synthesised by means of a metaanalysis. Last, we analysed and examined the role or mediating risk associated to both FP ownership and COVID-19.

\section{Results \\ Search results}

Our search strategy yielded 3,845 results, of which 3,514 were left after removal of duplicates. These were double-screened by ABM and MDE, after which 81 were independently assessed in full-text. Of these, 20 studies were deemed eligible for inclusion. A forward citation search was conducted on this sample every two weeks until January $26^{\text {th }}, 2021$, in order to identify emerging new research on the topic. An additional 9 eligible studies (primarily preprints and government reports) were identified through this process. Twenty-nine studies were thus included in the first version of this review. 

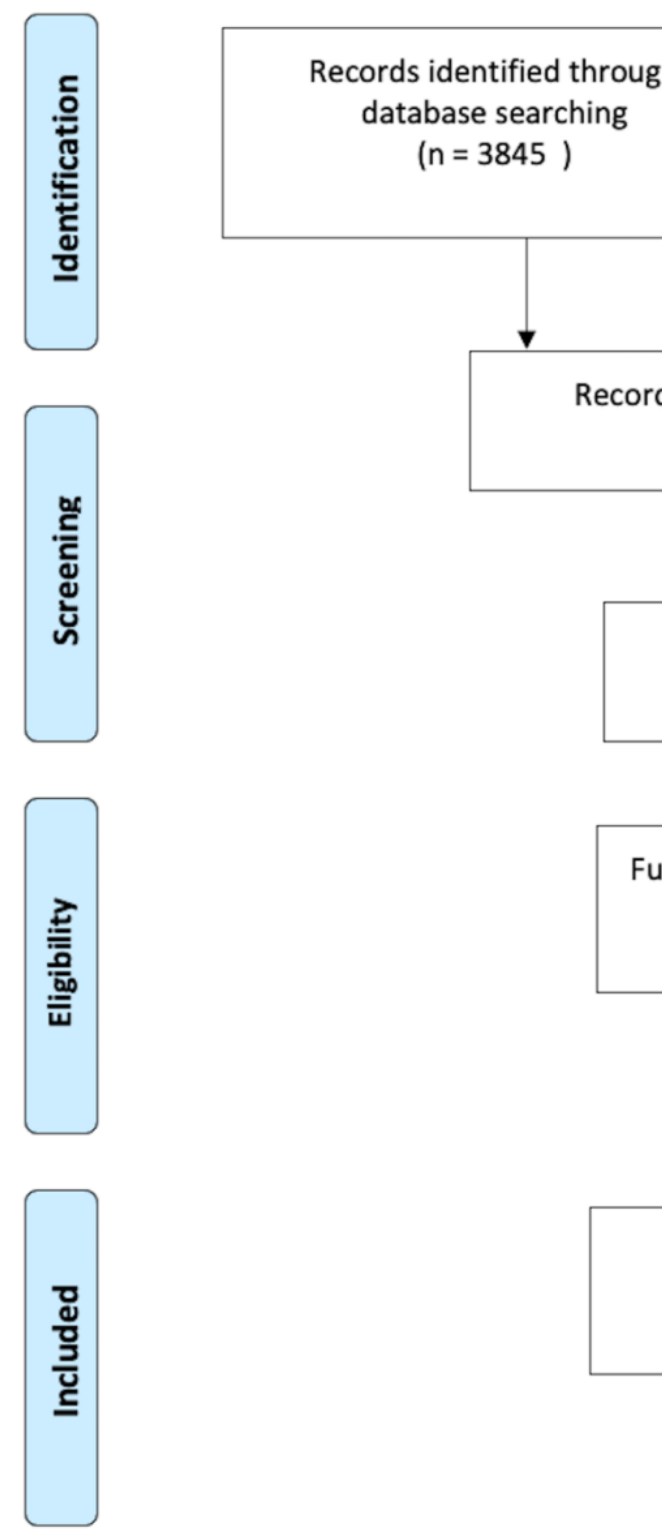

$$
(n=9)
$$

Figure 1: Prisma flow diagram.

\section{Description of studies}

The descriptive characteristics of all included research are shown in Table 1. Most of the included studies were peer-reviewed publications (24/29), with 2 government reports ${ }^{28,29}$ and 3 preprints or working papers. The unit of analysis across all included studies was care homes. For-profit care homes were the largest ownership group across all studies that provided detailed sample information. All except for two studies ${ }^{30,31}$ were published in July 2020 and after. Most studies were conducted in the United States (22/29), followed by Canada (3/29), England (2/29), Scotland $(1 / 29)$, and France $(1 / 29)$. Most included studies were considered cross-sectional and only three studies included more than one time-point in their analysis ${ }^{32-34}$.

Ownership was most commonly operationalised by comparing 'for-profit' (FP) and 'non-profit' (NP) care homes (17/29), usually with FPs as the reference category. Ten studies compared FPs and 
NPs (11/29), in which 'non-profits' also include public care homes, although this was not always explicitly described. Two studies focused on private equity (PE) providers in their operationalisation of ownership ${ }^{35,36}$. Eighteen studies adjusted for the chain affiliation (CA) of care homes to investigate COVID-19 related outcomes.

The most investigated outcome was COVID-19 outbreak (16/29), followed by COVID-19 related mortality (13/29), and incidence of COVID-19 infections (13/29). Five studies investigated staff access to PPE and/or shortage of PPE 33,35-38. Five studies investigated COVID-19 related outcomes among care home staff 36,39-41. Most studies investigated multiple COVID-19 outcomes. Three studies were published after initially being included as preprints ${ }^{31,41,42}$ and the results from the published versions are presented below. 
Table 1: Study and outcome characteristics

\begin{tabular}{|c|c|c|c|c|c|c|c|c|c|}
\hline Study & $\begin{array}{l}\text { Type of } \\
\text { study }\end{array}$ & $\begin{array}{l}\text { Publication } \\
\text { date }\end{array}$ & $\begin{array}{c}\text { Research } \\
\text { design }\end{array}$ & Country & $\begin{array}{c}\text { Operationalisation } \\
\text { of ownership }\end{array}$ & $\begin{array}{l}\text { Includes } \\
\text { chain? } \\
(\mathrm{y} / \mathrm{n})\end{array}$ & $\begin{array}{l}\text { Sample size } \\
\text { (care homes) }\end{array}$ & $\begin{array}{l}\text { Sample size across } \\
\text { ownership groups }\end{array}$ & COVID- 19 outcomes \\
\hline $\begin{array}{l}\text { (Bui et al., } \\
2020)^{28}\end{array}$ & $\begin{array}{l}\text { Government } \\
\text { report }\end{array}$ & $\begin{array}{l}\text { September } \\
2020\end{array}$ & $\begin{array}{l}\text { Cross- } \\
\text { sectional }\end{array}$ & $\begin{array}{l}\text { United States } \\
\text { (West Virginia) }\end{array}$ & $\begin{array}{l}\text { For-profit and non- } \\
\text { profit }\end{array}$ & $\mathrm{N}$ & 123 & $\begin{array}{l}\text { For-profit: } 95(77 \%) \\
\text { Non-profit: } 28(23 \%)\end{array}$ & $\begin{array}{l}\text { Outbreaks (two or more } \\
\text { cases) }\end{array}$ \\
\hline $\begin{array}{l}\text { (Chatterjee, } \\
\text { Kelly, Qi, \& } \\
\text { Werner, 2020) } \\
43\end{array}$ & $\begin{array}{l}\text { Peer-reviewed } \\
\text { publication }\end{array}$ & July 2020 & $\begin{array}{l}\text { Cross- } \\
\text { sectional }\end{array}$ & $\begin{array}{l}\text { United States } \\
(23 \text { States) }\end{array}$ & $\begin{array}{l}\text { For-profit and non- } \\
\text { profit }\end{array}$ & $\mathrm{N}$ & 8,943 & $\begin{array}{l}\text { For-profit: } 6473(72 \%) \\
\text { Non-profit: } 2470(28 \%)\end{array}$ & Outbreaks (any cases) \\
\hline $\begin{array}{l}\text { (Abrams, } \\
\text { Loomer, } \\
\text { Gandhi, \& } \\
\text { Grabowski, } \\
2020)^{44}\end{array}$ & $\begin{array}{l}\text { Peer-reviewed } \\
\text { publication }\end{array}$ & June 2020 & $\begin{array}{l}\text { Cross- } \\
\text { sectional }\end{array}$ & $\begin{array}{l}\text { United states ( } 30 \\
\text { States) }\end{array}$ & $\begin{array}{l}\text { For-profit, non-profit } \\
\text { and public }\end{array}$ & $\mathrm{Y}$ & 9,395 & $\begin{array}{l}\text { For-profit: } 6878(73 \%) \\
\text { Non-profit: } 2178(23 \%) \\
\text { Government: } 339(4 \%)\end{array}$ & $\begin{array}{l}\text { Outbreaks (any cases) } \\
\text { and number of } \\
\text { infections }\end{array}$ \\
\hline $\begin{array}{l}\text { (Braun et al., } \\
2020)^{35}\end{array}$ & $\begin{array}{l}\text { Peer-reviewed } \\
\text { publication }\end{array}$ & October 2020 & $\begin{array}{l}\text { Cross- } \\
\text { sectional }\end{array}$ & $\begin{array}{l}\text { United States } \\
\text { (unclear number } \\
\text { of states) }\end{array}$ & $\begin{array}{l}\text { Private-equity, for- } \\
\text { profit non-profit, and } \\
\text { public }\end{array}$ & $\mathrm{Y}$ & 11,470 & $\begin{array}{l}\text { For-profit: } 7793(67.9 \%) \\
\text { Non-profit: } 2523(22.0 \%) \\
\text { Government: } 511(5.3 \%) \\
\text { Private equity: } 543(4.7 \%)\end{array}$ & $\begin{array}{l}\text { Number of infections } \\
\text { and deaths pr } 1,000 \\
\text { residents, supply of } \\
\text { PPE, and staffing } \\
\text { shortage }\end{array}$ \\
\hline $\begin{array}{l}\text { (Yue Li, } \\
\text { Temkin- } \\
\text { Greener, Gao, } \\
\text { \& Cai, 2020) }\end{array}$ & $\begin{array}{l}\text { Peer-reviewed } \\
\text { publication }\end{array}$ & June 2020 & $\begin{array}{l}\text { Cross- } \\
\text { sectional }\end{array}$ & $\begin{array}{l}\text { United States } \\
\text { (Connecticut) }\end{array}$ & $\begin{array}{l}\text { For-profit and non- } \\
\text { profit (including } \\
\text { public providers) }\end{array}$ & $\mathrm{Y}$ & 215 & $\begin{array}{l}\text { For-profit } 179(83 \%) \\
\text { Non-Profit: } 36(17 \%)\end{array}$ & $\begin{array}{l}\text { Number of infections } \\
\text { and deaths }\end{array}$ \\
\hline $\begin{array}{l}\text { (Yumeng Li, } \\
\text { Fang, \& He, } \\
2020)_{45}\end{array}$ & $\begin{array}{l}\text { Peer-reviewed } \\
\text { publication }\end{array}$ & October 2020 & $\begin{array}{l}\text { Cross- } \\
\text { sectional }\end{array}$ & $\begin{array}{l}\text { United States } \\
\text { (unclear number } \\
\text { of states) }\end{array}$ & $\begin{array}{l}\text { For-profit, non-profit } \\
\text { and public }\end{array}$ & $\mathrm{Y}$ & 14,062 & $\begin{array}{l}\text { For-profit: 9,787 }(70 \%) \\
\text { Government: } 903(6.5 \%) \\
\text { Non-profit: } 3286(23.5 \%)\end{array}$ & Supply of PPE \\
\hline $\begin{array}{l}\text { (Stall, Jones, } \\
\text { Brown, } \\
\text { Rochon, \& } \\
\text { Costa, 2020) }{ }^{46}\end{array}$ & $\begin{array}{l}\text { Peer-reviewed } \\
\text { publication }\end{array}$ & August 2020 & $\begin{array}{l}\text { Cross- } \\
\text { sectional }\end{array}$ & Canada Ontario & $\begin{array}{l}\text { For-profit, non- } \\
\text { profit, and public }\end{array}$ & Y & 623 & $\begin{array}{l}\text { For-profit: } 360(57.7 \%) \\
\text { Non-profit: } 162(26.0 \%) \\
\text { Government: } 101(16.2 \%)\end{array}$ & $\begin{array}{l}\text { Outbreaks (any cases), } \\
\text { number of infections, } \\
\text { and deaths }\end{array}$ \\
\hline $\begin{array}{l}(\mathrm{He}, \mathrm{Li}, \& \\
\text { Fang, 2020) }\end{array}$ & $\begin{array}{l}\text { Peer-reviewed } \\
\text { publication }\end{array}$ & June 2020 & $\begin{array}{l}\text { Cross- } \\
\text { sectional }\end{array}$ & $\begin{array}{l}\text { United States } \\
\text { (California) }\end{array}$ & $\begin{array}{l}\text { For-profit, non- } \\
\text { profit, and public }\end{array}$ & $\mathrm{N}$ & 1,144 & $\begin{array}{l}\text { For-profit: } 956(84 \%) \\
\text { Government: } 35(3 \%) \\
\text { Non-profit: } 153(13 \%)\end{array}$ & $\begin{array}{l}\text { Number of infections } \\
\text { and deaths }\end{array}$ \\
\hline $\begin{array}{l}\text { (Sugg et al., } \\
2021)^{48}\end{array}$ & $\begin{array}{l}\text { Peer-reviewed } \\
\text { publication }\end{array}$ & August 2020 & $\begin{array}{l}\text { Cross- } \\
\text { sectional }\end{array}$ & $\begin{array}{l}\text { United States } \\
\text { (unclear number } \\
\text { of states) }\end{array}$ & $\begin{array}{l}\text { For-profit, non- } \\
\text { profit, and public }\end{array}$ & $\mathrm{N}$ & 13,709 & Unclear & Number of infections \\
\hline $\begin{array}{l}\text { (Dean, } \\
\text { Venkataraman } \\
\text { i, \& Kimmel, } \\
\text { 2020) }{ }^{49}\end{array}$ & $\begin{array}{l}\text { Peer-reviewed } \\
\text { publication }\end{array}$ & $\begin{array}{l}\text { November } \\
2020\end{array}$ & $\begin{array}{l}\text { Cross- } \\
\text { sectional }\end{array}$ & $\begin{array}{l}\text { United States } \\
\text { (NY state) }\end{array}$ & $\begin{array}{l}\text { For-profit and non- } \\
\text { profit }\end{array}$ & $\mathrm{Y}$ & 621 & Unclear & Deaths \\
\hline $\begin{array}{l}\text { (Harrington et } \\
\text { al., 2020) } 50\end{array}$ & $\begin{array}{l}\text { Peer-reviewed } \\
\text { publication }\end{array}$ & July 2020 & $\begin{array}{l}\text { Cross- } \\
\text { sectional }\end{array}$ & $\begin{array}{l}\text { United States } \\
\text { (California) }\end{array}$ & $\begin{array}{l}\text { For-profit, non-profit } \\
\text { (including public) }\end{array}$ & $\mathrm{N}$ & 1,091 & $\begin{array}{l}\text { For-profit: } 920(84 \%) \\
\text { non-profit \& government: } \\
171(16 \%)\end{array}$ & Outbreaks (any cases) \\
\hline $\begin{array}{l}\text { (Unruh, Yun, } \\
\text { Zhang, Braun, } \\
\text { \& Jung, 2020) } \\
30\end{array}$ & $\begin{array}{l}\text { Peer-reviewed } \\
\text { publication }\end{array}$ & June 2020 & $\begin{array}{l}\text { Cross- } \\
\text { sectional }\end{array}$ & $\begin{array}{l}\text { United States } \\
\text { (Connecticut, } \\
\text { New Jersey, } \\
\text { New York) }\end{array}$ & $\begin{array}{l}\text { For-profit and non- } \\
\text { profit }\end{array}$ & $\mathrm{Y}$ & 1,162 & Unclear & $\begin{array}{l}\text { Deaths (dichotomised as } \\
6 \text { or more) }\end{array}$ \\
\hline
\end{tabular}




\begin{tabular}{|c|c|c|c|c|c|c|c|c|c|}
\hline $\begin{array}{l}\text { (Bowblis \& } \\
\text { Applebaum, } \\
\text { 2020) }{ }^{32}\end{array}$ & $\begin{array}{l}\text { Peer-reviewed } \\
\text { publication }\end{array}$ & October 2020 & Cohort & $\begin{array}{l}\text { United States } \\
\text { (Ohio) }\end{array}$ & $\begin{array}{l}\text { For-profit, non- } \\
\text { profit, and public }\end{array}$ & $\mathrm{Y}$ & 942 & $\begin{array}{l}\text { For-profit: } 749(79.4 \%) \\
\text { Non-profit: } 178(19 \%) \\
\text { Government: } 15(1.6 \%)\end{array}$ & $\begin{array}{l}\text { Outbreaks and number } \\
\text { of infections } \\
\text { (dichotomised as more } \\
\text { than } 20 \% \text { of residents) }\end{array}$ \\
\hline $\begin{array}{l}\text { (Yue Li, Cen, } \\
\text { Cai, \& } \\
\text { Temkin- } \\
\text { Greener, } \\
\text { 2020) } \\
\text { 39 }\end{array}$ & $\begin{array}{l}\text { Peer-reviewed } \\
\text { publication }\end{array}$ & $\begin{array}{l}\text { September } \\
2020\end{array}$ & $\begin{array}{l}\text { Cross- } \\
\text { sectional }\end{array}$ & $\begin{array}{l}\text { United States } \\
\text { (unclear number } \\
\text { of states) }\end{array}$ & $\begin{array}{l}\text { For-profit, non- } \\
\text { profit, and public }\end{array}$ & $\mathrm{Y}$ & 12,576 & $\begin{array}{l}\text { For-profit: 8,861 }(70 \%) \\
\text { Non-profit: } 2,938(23 \%) \\
\text { Government: } 777(7 \%)\end{array}$ & $\begin{array}{l}\text { Number of infections } \\
\text { and deaths }\end{array}$ \\
\hline $\begin{array}{l}\text { (Fisman, } \\
\text { Bogoch, } \\
\text { Lapointe- } \\
\text { Shaw, } \\
\text { McCready, \& } \\
\text { Tuite, 2020) }{ }^{51}\end{array}$ & $\begin{array}{l}\text { Peer-reviewed } \\
\text { publication }\end{array}$ & July 2020 & $\begin{array}{l}\text { Cross- } \\
\text { sectional }\end{array}$ & $\begin{array}{l}\text { Canada } \\
\text { (Ontario) }\end{array}$ & $\begin{array}{l}\text { For-profit, non- } \\
\text { profit, municipal, and } \\
\text { charitable }\end{array}$ & $\mathrm{N}$ & 627 & $\begin{array}{l}\text { For-profit: } 361(57 \%) \\
\text { Non-profit: } 117(18 \%) \\
\text { Municipal: } 101(16 \%) \\
\text { Charitable: } 57(9 \%)\end{array}$ & Outbreaks (any cases) \\
\hline $\begin{array}{l}\text { Xu, Intrator, } \\
\& \text { Bowblis, } \\
2020)^{37}\end{array}$ & $\begin{array}{l}\text { Peer-reviewed } \\
\text { publication }\end{array}$ & August 2020 & $\begin{array}{l}\text { Cross- } \\
\text { sectional }\end{array}$ & $\begin{array}{l}\text { United States } \\
\text { (unclear number } \\
\text { of states) }\end{array}$ & $\begin{array}{l}\text { For-profit, non- } \\
\text { profit, and public }\end{array}$ & $\mathrm{Y}$ & 11,920 & $\begin{array}{l}\text { For-profit: } 8561(72 \%) \\
\text { government: } 647(5 \%) \\
\text { Not-for-profit: } 2712(23 \%)\end{array}$ & Shortage of staff \\
\hline $\begin{array}{l}\text { (Gorges \& } \\
\text { Konetzka, } \\
2020)^{52}\end{array}$ & $\begin{array}{l}\text { Peer-reviewed } \\
\text { publication }\end{array}$ & August 2020 & $\begin{array}{l}\text { Cross- } \\
\text { sectional }\end{array}$ & $\begin{array}{l}\text { United States } \\
\text { (unclear number } \\
\text { of states) }\end{array}$ & $\begin{array}{l}\text { For-profit, non- } \\
\text { profit, and public }\end{array}$ & $\mathrm{Y}$ & 13,167 & $\begin{array}{l}\text { For-profit: } 9164(69.6 \%) \\
\text { Non-profit: } 3265(24.8 \%) \\
\text { Government: } 737(5.6 \%)\end{array}$ & $\begin{array}{l}\text { Outbreak (any cases), } \\
\text { number of infections } \\
\text { (dichotomised as } \\
>10 \% \text { confirmed } \\
\text { cases/beds or }>20 \% \\
\text { confirmed }+ \text { suspected } \\
\text { cases/beds, or } 10+ \\
\text { deaths), and deaths }\end{array}$ \\
\hline $\begin{array}{l}\text { (McGarry, } \\
\text { Grabowski, \& } \\
\text { Barnett, 2020) } \\
\text { 33 }\end{array}$ & $\begin{array}{l}\text { Peer-reviewed } \\
\text { publication }\end{array}$ & October 2020 & Cohort & $\begin{array}{l}\text { United States } \\
\text { (unclear number } \\
\text { of states) }\end{array}$ & $\begin{array}{l}\text { For-profit, non- } \\
\text { profit, and public }\end{array}$ & $\mathrm{Y}$ & 15,035 & $\begin{array}{l}\text { For-profit } 10539(70.1 \%) \\
\text { Non-profit: } 3518(23.4 \%) \\
\text { Government: } 977(6.5 \%)\end{array}$ & PPE and staff shortage \\
\hline $\begin{array}{l}\text { (Gibson \& } \\
\text { Greene, 2020) } \\
38\end{array}$ & $\begin{array}{l}\text { Peer-reviewed } \\
\text { publication }\end{array}$ & October 2020 & $\begin{array}{l}\text { Cross- } \\
\text { sectional }\end{array}$ & $\begin{array}{l}\text { United States } \\
\text { (unclear number } \\
\text { of states) }\end{array}$ & $\begin{array}{l}\text { For-profit, non- } \\
\text { profit, and public }\end{array}$ & $\mathrm{Y}$ & 13,445 & $\begin{array}{l}\text { For-profit: } 9398(69.9 \%) \\
\text { Non-profit: } 3200(23.8 \%) \\
\text { Government: } 847(6.3 \%)\end{array}$ & $\begin{array}{l}\text { Supply of PPE and staff } \\
\text { shortage }\end{array}$ \\
\hline $\begin{array}{l}\text { (Rowan et al., } \\
2020)^{29}\end{array}$ & $\begin{array}{l}\text { Report by } \\
\text { Mathematica }\end{array}$ & $\begin{array}{l}\text { September } \\
2020\end{array}$ & $\begin{array}{l}\text { Cross- } \\
\text { sectional }\end{array}$ & $\begin{array}{l}\text { United States } \\
\text { (Connecticut) }\end{array}$ & $\begin{array}{l}\text { For-profit and non- } \\
\text { profit }\end{array}$ & $\mathrm{Y}$ & 212 & $\begin{array}{l}\text { For-profit: } 176(83 \%) \\
\text { Non-profit: } 36(17 \%)\end{array}$ & $\begin{array}{l}\text { Outbreak (any cases), } \\
\text { number of infections, } \\
\text { and deaths per licensed } \\
\text { bed }\end{array}$ \\
\hline $\begin{array}{l}\text { (Brown et al., } \\
2020)^{31}\end{array}$ & $\begin{array}{l}\text { Peer-reviewed } \\
\text { publication } \\
\text { (initially } \\
\text { included as } \\
\text { preprint) }\end{array}$ & $\begin{array}{l}\text { November } \\
2020\end{array}$ & $\begin{array}{l}\text { Cross- } \\
\text { sectional }\end{array}$ & $\begin{array}{l}\text { Canada } \\
\text { (Ontario) }\end{array}$ & $\begin{array}{l}\text { For-profit, non- } \\
\text { profit, and public } \\
\text { (municipal). }\end{array}$ & $\mathrm{N}$ & 618 & $\begin{array}{l}\text { For-profit: } 358(58 \%) \\
\text { Non-profit: } 159(26 \%) \\
\text { Municipal: } 101(16 \%)\end{array}$ & $\begin{array}{l}\text { Outbreaks (any cases), } \\
\text { number of infections } \\
\text { and deaths per } 100 \\
\text { residents }\end{array}$ \\
\hline $\begin{array}{l}\text { (Burton et al., } \\
2020)^{53}\end{array}$ & $\begin{array}{l}\text { Peer-reviewed } \\
\text { publication }\end{array}$ & October 2020 & $\begin{array}{l}\text { Cross- } \\
\text { sectional }\end{array}$ & Scotland & $\begin{array}{l}\text { For-profit, non- } \\
\text { profit, and public } \\
\text { (local authority) }\end{array}$ & $\mathrm{N}$ & 189 & $\begin{array}{l}\text { Private: } 98(52 \%) \\
\text { Local authority: } 54(28 \%) \\
\text { Non-profit: } 37(20 \%)\end{array}$ & Outbreaks (any cases) \\
\hline (Shen, 2020) ${ }^{54}$ & $\begin{array}{l}\text { Medrxiv } \\
\text { preprint }\end{array}$ & $\begin{array}{l}\text { September } \\
2020\end{array}$ & $\begin{array}{l}\text { Cross- } \\
\text { sectional }\end{array}$ & $\begin{array}{l}\text { United States } \\
\text { (18 states) }\end{array}$ & $\begin{array}{l}\text { For-profit and non- } \\
\text { profit (including } \\
\text { public) }\end{array}$ & $\mathrm{Y}$ & 6,132 & $\begin{array}{l}\text { For-profit: } 4476(73 \%) \\
\text { Non-profit: } 1472(24 \%) \\
\text { Public: } 184(3 \%)\end{array}$ & $\begin{array}{l}\text { Number of deaths per } \\
100 \text { beds }\end{array}$ \\
\hline
\end{tabular}




\begin{tabular}{|c|c|c|c|c|c|c|c|c|c|}
\hline $\begin{array}{l}\text { (Chen, } \\
\text { Chevalier, \& } \\
\text { Long, 2020) }\end{array}$ & $\begin{array}{l}\text { Peer-reviewed } \\
\text { publication } \\
\text { (initially } \\
\text { included as } \\
\text { preprint) }\end{array}$ & $\begin{array}{l}\text { December } \\
2020\end{array}$ & $\begin{array}{l}\text { Cross- } \\
\text { sectional }\end{array}$ & $\begin{array}{l}\text { United States } \\
\text { (22 states) }\end{array}$ & $\begin{array}{l}\text { For-profit and non- } \\
\text { profit }\end{array}$ & $\mathrm{N}$ & 6,337 & $\begin{array}{l}\text { For-profit: } 4689(74 \%) \\
\text { Non-profit: } 1648(26 \%)\end{array}$ & $\begin{array}{l}\text { Number of cases } \\
\text { (inverse hyperbolic sine) }\end{array}$ \\
\hline $\begin{array}{l}\text { (Gandhi, } \\
\text { Song, \& } \\
\text { Upadrashta, } \\
2020)^{36}\end{array}$ & Preprint & October 2020 & $\begin{array}{l}\text { Cross- } \\
\text { sectional }\end{array}$ & $\begin{array}{l}\text { United States } \\
\text { (49 states) }\end{array}$ & $\begin{array}{l}\text { Private equity, } \\
\text { prior private equity, } \\
\text { and } \\
\text { for-profit }\end{array}$ & $\mathrm{Y}$ & 13,398 & $\begin{array}{l}\text { Non-Private equity: } 11,788 \\
(88 \%) \\
\text { Prior Private equity: } 1,219 \\
(9 \%) \\
\text { Private equity: } 391(3 \%) \\
\text { No info on for-profit }\end{array}$ & $\begin{array}{l}\text { Number of confirmed } \\
\text { and suspected } \\
\text { infections, deaths, and } \\
\text { PPE shortage }\end{array}$ \\
\hline $\begin{array}{l}\text { (Shallcross et } \\
\text { al., 2020) }\end{array}$ & $\begin{array}{l}\text { Peer-reviewed } \\
\text { publication } \\
\text { (initially } \\
\text { included as } \\
\text { preprint) }\end{array}$ & February 2021 & $\begin{array}{l}\text { Cross- } \\
\text { sectional }\end{array}$ & England & $\begin{array}{l}\text { For-profit and non- } \\
\text { profit }\end{array}$ & $\mathrm{Y}$ & 5,126 & $\begin{array}{l}\text { Profit: } 4289(83.7 \%) \\
\text { Not-for-profit: } 837(16.3 \%)\end{array}$ & $\begin{array}{l}\text { Outbreaks (any cases) } \\
\text { and number of } \\
\text { infections (dichotomised } \\
\text { as more than one third } \\
\text { of staff or residents) }\end{array}$ \\
\hline $\begin{array}{l}\text { (Rolland et al., } \\
2020)^{15}\end{array}$ & $\begin{array}{l}\text { Peer-reviewed } \\
\text { publication }\end{array}$ & July 2020 & $\begin{array}{l}\text { Cross- } \\
\text { sectional }\end{array}$ & France & $\begin{array}{l}\text { For-profit, non- } \\
\text { profit, and public }\end{array}$ & $\mathrm{N}$ & 124 & $\begin{array}{l}\text { For-profit: } 54(44 \%) \\
\text { Non-profit: } 35(28 \%) \\
\text { Public: } 35(28 \%)\end{array}$ & Outbreaks (any cases) \\
\hline $\begin{array}{l}\text { (Morciano, } \\
\text { Stokes, } \\
\text { Kontopanteli, } \\
\text { Hall, \& } \\
\text { Turner, 2020) } \\
34\end{array}$ & $\begin{array}{l}\text { Medrxiv } \\
\text { preprint }\end{array}$ & $\begin{array}{l}\text { November } \\
2020\end{array}$ & Cohort & England & $\begin{array}{l}\text { For-profit and non- } \\
\text { profit }\end{array}$ & Y & 15,524 & $\begin{array}{l}\text { For-profit: } 13397(86.3 \%) \\
\text { Non-profit: } 2127(14.7 \%)\end{array}$ & $\begin{array}{l}\text { Deaths (defined as at } \\
\text { least one suspected or } \\
\text { confirmed COVID-19 } \\
\text { death) }\end{array}$ \\
\hline $\begin{array}{l}\text { (Gopal, Han, } \\
\& \text { Yaraghi, } \\
\text { 2021) }\end{array}$ & $\begin{array}{l}\text { Peer-reviewed } \\
\text { publication }\end{array}$ & January 2021 & $\begin{array}{l}\text { Cross- } \\
\text { sectional }\end{array}$ & $\begin{array}{l}\text { United States } \\
\text { (California) }\end{array}$ & $\begin{array}{l}\text { For-profit and non- } \\
\text { profit }\end{array}$ & $\mathrm{N}$ & 713 & $\begin{array}{l}\text { For-profit: } 613(86 \%) \\
\text { Non-profit: } 100(14 \%)\end{array}$ & $\begin{array}{l}\text { Outbreaks (any cases) } \\
\text { and number of } \\
\text { infections among } \\
\text { residents and staff }\end{array}$ \\
\hline
\end{tabular}

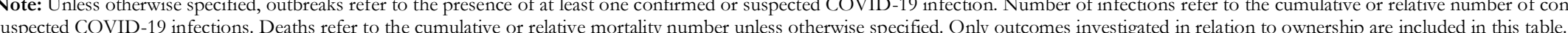




\section{Data sources and time coverage}

Most of the included research merged multiple data sources on COVID-19 outcomes, information on the care homes, and area characteristics to construct their dataset. Less than $15 \%$ of included studies (4/29) collected primary data on the investigated COVID-19 outcomes. The majority of studies used data routinely reported by care homes to public health departments and other government-collected data. Almost a third of the included studies (9/29) used data from the Centers for Medicare \& Medicaid Services (CMS), who required American nursing homes to report COVID19 related data, including confirmed and suspected infections and deaths among residents and staff

${ }^{55}$ from May 24. Providers were encouraged, but not required, to retrospectively self-report COVID19 outcomes before this date. Table A2 in the supplementary material provides an overview of the data sources and the time period of the dependent variables across all included studies.

Eighteen studies reported on self-reported (confirmed and suspected cases) COVID-19 outcomes, whereas 19 studies only investigated confirmed COVID-19 outcomes. In one study, it was unclear if the investigated outcomes were confirmed or self-reported. All studies that investigated PPE and staffing shortage relied on self-reported outcomes. Most studies investigated COVID-19 outcomes collected in the March to July timespan with only two studies including data from later than September, $2020{ }^{54}$. Most studies investigated outcomes covering a 1-2 months period although five studies investigated a period of less than two weeks ${ }^{36,37,39,43,45}$. The findings presented below thus relate to the first wave of the pandemic.

\section{Risk of bias assessments}

The RoB assessments are detailed in Table A3 in the supplementary material. The main concerns related to systematic missing data and selection bias in the included studies. For example, studies that investigated the characteristics of excluded observations from the CMS dataset (due to missing or incomplete data) found that excluded care homes were more likely to be FP and were also associated to many risk factors, such as the ethnicity and socio-economic status of residents (discussed in detail below) ${ }^{33,37-39}$. This is a potentially serious limitation of the studies using this data (for the purpose of this review), as it suggests that poorly performing FPs may be systematically underrepresented in the sample, which may underestimate the observed effect of ownership on COVID-19 outcomes. Because of this limitation, all studies using this dataset were downgraded to (at least) moderate risk. For studies using public and government data, we assumed the risk of information bias to be low.

All assessments of confounding bias done as part of the RoB were based on consideration of factors known to exacerbate the effect of COVID-19 ${ }^{56-59}$ and the performance of care homes for older people ${ }^{6,7}$. Almost all studies adjusted for the size of the care homes $(24 / 29)$, and characteristics on quality and staffing were also commonly included. However, only 5 studies adjusted their outcome(s) to the number of beds or residents ${ }^{29,31,35,42,54}$. Nineteen studies adjusted for the ethnic composition and 15/29 included information about the socio-economic status of residents. Rurality and/or population density was included in 11/29 of the studies and local/community incidence of COVID-19 were controlled for in 17/29 of the studies. See Table A4 in the supplementary material for details on the direction of effect and model adjustment of all included studies.

\section{Direction of effects}

Figure 2 displays the direction of effect for all included studies across different ownership and COVID-19 outcomes. Bar height indicates overall risk of bias (with taller bars indicating lower RoB) 
medRxiv preprint doi: https://doi.org/10.1101/2021.01.28.21250547; this version posted February 23, 2021. The copyright holder for this preprint (which was not certified by peer review) is the author/funder, who has granted medRxiv a license to display the preprint in perpetuity. It is made available under a CC-BY-NC-ND 4.0 International license .

and colour denotes country context. See Figure A1 in the supplementary material for a harvest plot on the direction of effect across different data sources and Table 2 for details on the confidence of each finding. 
Table 2: Overview of outcomes and confidence in findings.

\begin{tabular}{|c|c|c|c|c|c|c|c|c|c|c|c|c|c|}
\hline & \multicolumn{4}{|c|}{ COVID-19 outbreaks } & \multicolumn{3}{|c|}{ Covid-19 incidence } & \multicolumn{3}{|c|}{ COVID-19 mortality } & \multicolumn{3}{|c|}{ PPE or staffing shortage } \\
\hline & $\begin{array}{l}\text { Positive } \\
\text { association }\end{array}$ & No a & fference & $\begin{array}{l}\text { Negative } \\
\text { association }\end{array}$ & $\begin{array}{l}\text { Positive } \\
\text { association }\end{array}$ & No difference & $\begin{array}{l}\text { Negative } \\
\text { association }\end{array}$ & $\begin{array}{l}\text { Positive } \\
\text { association }\end{array}$ & $\begin{array}{l}\text { No } \\
\text { difference }\end{array}$ & $\begin{array}{l}\text { Negative } \\
\text { association }\end{array}$ & $\begin{array}{l}\text { Positive } \\
\text { association }\end{array}$ & $\begin{array}{l}\text { No } \\
\text { difference }\end{array}$ & $\begin{array}{l}\text { Negative } \\
\text { association }\end{array}$ \\
\hline \multicolumn{14}{|c|}{ Resident outcomes } \\
\hline $\begin{array}{l}\text { For-profit } \\
\text { (vs non- } \\
\text { profits, } \\
\text { public, or } \\
\text { non-profits } \\
\text { and public) }\end{array}$ & $15,36,43$ & $\begin{array}{l}28,29,3 \\
46,48,5\end{array}$ & $\begin{array}{l}, 32,40,41,44, \\
, 51,53\end{array}$ & 52 & $\begin{array}{l}14,31,36,40- \\
42,44,47,52\end{array}$ & $29,32,39,46,48$ & & $30,31,36,47,52,54$ & $\begin{array}{l}14,29,34,39,46 \\
, 49\end{array}$ & & $\begin{array}{l}\text { PPE: } \\
33,36,38,45 \\
\text { Clinical } \\
\text { staff: }{ }^{37}\end{array}$ & $\begin{array}{l}\text { Staffing: } \\
33,38\end{array}$ & \\
\hline $\begin{array}{l}\text { Chain } \\
\text { affiliation } \\
\text { (vs non- } \\
\text { chain } \\
\text { affiliated) }\end{array}$ & $29,32,36,52$ & 41,46 & & 44 & 36,46 & $\begin{array}{l}14,29,32,35,39,41,44 \\
, 52\end{array}$ & & $34,36,46,49,54$ & $\begin{array}{l}14,29,30,35,39 \\
, 52\end{array}$ & & $\begin{array}{l}\text { PPE: } \\
33,36\end{array}$ & $\begin{array}{l}\text { PPE: } \\
35,38,45 \\
\text { Staffing: } \\
35,37,38\end{array}$ & $\begin{array}{l}\text { Staffing: } \\
\text { Nursing } \\
\text { staff: } 35\end{array}$ \\
\hline $\begin{array}{l}\text { Private } \\
\text { equity (vs } \\
\text { non PE } \\
\text { owned) }\end{array}$ & & & & 36 & & 35 & 36 & & 35,36 & & $\begin{array}{l}\text { Masks: } \\
35\end{array}$ & $\begin{array}{l}\text { Staffing: } \\
35\end{array}$ & PPE: 36 \\
\hline \multicolumn{14}{|c|}{ Staff outcomes } \\
\hline For-profit & 41 & 36 & & & 41 & 39,40 & & & 36 & & & & \\
\hline $\begin{array}{l}\text { Chain } \\
\text { affiliation }\end{array}$ & & 41 & & & 36 & 39 & & 36 & & & & & \\
\hline \multicolumn{14}{|c|}{ Confidence ratings $\quad$ Colour codes Description } \\
\hline \multicolumn{14}{|c|}{$\begin{array}{l}\text { High confidence } \\
\text { Moderate confidence }\end{array} \begin{array}{l}\text { To achieve high confidence, a finding must be supported by multiple studies with low to moderate risk of bias, and the finding must be consistent across multiple model } \\
\text { specifications. The finding must also be supported in more than one research context. } \\
\text { This confidence rating is given to findings which are supported by multiple studies with moderate to high risk of bias, and where there are some concerns regarding } \\
\text { consistency. } \\
\text { This confidence rating is given to findings supported by multiple studies with high risk of bias or single studies with moderate to high risk of bias in single research contexts. }\end{array}$} \\
\hline
\end{tabular}

Note: The numbers in each cell refer to the study references supporting that finding. If available, we present the adjusted results. Positive and negative associations are

understood as associations in either direction that are statistically significant at the $5 \%$ level. No difference is understood as differences that are not statistically significant.

Outbreaks usually refer to the presence of any COVID-19 infections, except for one study that defined outbreaks as at least two cases 28 . COVID-19 incidence usually

refers to the cumulative number of COVID-19 infections, but also includes binary outcomes on large outbreaks (e.g. ${ }^{41,52}$ ). COVID-19 mortality usually refers to

cumulative cases, except for one study which used a binary indicator of at least 6 deaths ${ }^{30}$, and another which analysed a dichotomised outcome of any number of deaths vs no deaths 34 


\section{Resident outcomes}

In most studies investigating outbreaks (12/15) among residents, FP ownership was not associated with a higher risk of outbreak, suggesting that FP care homes were not more or less likely to have at least one infected resident. For-profit care homes were usually found to be associated with a higher number of cumulative COVID-19 infections. This direction of effect (i.e., positive effect) was coherent across multiple contexts, including the US, England, and Canada. No studies found FP ownership to be associated with fewer COVID-19 infections.

The evidence on COVID-19 mortality among residents and FP ownership was mixed. Six studies found higher rates of COVID-19 related deaths in FP care homes in Canada (Ontario ${ }^{31}$ ), California ${ }^{47}$, and across aggregated samples of US states ${ }^{30,36,52,54}$, whereas six studies analysing data from Canada (Ontario ${ }^{46}$ ), England ${ }^{34}$, Connecticut ${ }^{14,29}$, New York state ${ }^{49}$, and a single study using aggregate data from multiple states ${ }^{39}$ did not find a statistically significant association. However, the English study only investigated variation in the probability of having at least 1 COVID-19 related death and did not analyse variation in the cumulative numbers of deaths ${ }^{34}$. More importantly, most of the US studies (4/5) which analysed cumulative state data (as opposed to data from single states) reported a statistically significant relationship between FP ownership and mortality ${ }^{30,36,52,54}$. The only study using cumulative state data which did not identify statistically significant ownership variation analysed COVID-19 deaths for only one week (May 25 to May 31, 2020) ${ }^{39}$. The opposing results regarding ownership in Canada (Ontario) are discussed in the below section. No studies found FP ownership to be associated with fewer COVID-19 deaths.

All studies that investigated PPE outcomes found FP ownership to be positively associated with insufficient access to or shortage of PPE $33,36,38,45$. FP ownership was not consistently associated with staffing shortages.

[Figure 2 here]

Chain affiliated care homes were generally associated with a higher likelihood of COVID-19 outbreaks, but not with a higher incidence of infections. Five studies from Canada, England, and the US found CA ownership to be associated with a higher incidence of COVID-19 deaths, whereas 6 studies using both single and cumulative US state data did not identify any statistically significant variation. The one Canadian study that investigated this ownership category found CA care homes to be associated with more COVID-19 infections and deaths ${ }^{46}$. The two English studies investigating this group did not identify any variation in outbreaks and incidence across chain ownership ${ }^{41}$, but one found CA care homes to be associated with higher risk of at least one COVID-19 death among residents ${ }^{34}$.

Care homes owned by private equity (PE) firms were not found to be consistently associated with worse outcomes than other ownership categories, and one study even found PE providers to be less likely to report PPE shortages and confirmed COVID-19 outbreaks ${ }^{36}$.

\section{Staff outcomes}

Evidence on the relationship between ownership variation and risk of infection among staff was modest, with only four studies investigating this population. In England, FP ownership was associated with a higher incidence of infection among staff ${ }^{41}$, but there was no difference for CA care homes. The three studies conducted in the US did not identify any statistically significant 
variation related to FP ownership, but one study found CA care homes to be correlated with a higher risk of infection and deaths among staff ${ }^{36}$.

\section{Indirect ownership effects}

Most studies reported the unadjusted prevalence of deaths and infections to be higher in FP care homes, but this effect was not always statistically significant when adjusting for covariates. This suggest that there are important mediating factors that influence the effect of ownership on COVID-19 outcomes. However, ownership was usually treated as a covariate for model adjustment, and the specific results relating to this variable were not often directly discussed and interpreted. For the studies which did discuss the effect of ownership on COVID-19 (16/29), the below mentioned mediating pathways were considered most important.

For-profit care homes were more likely to report PPE shortages ${ }^{33,35,38}$, which will inevitably have influenced their ability to safeguard residents in the early wave of the pandemic. Some interpreted this association to mean that FP care homes were less willing to challenge the financial bottom-line by making additional investments, even during a pandemic ${ }^{14,33}$. Yet private equity did not report PPE shortages ${ }^{35,36}$, raising questions about whether the profit motive is the main driving factor.

Table 3: Overview of risk factors associated to both FP ownership and COVID-19 outcomes.

\begin{tabular}{|c|c|c|}
\hline $\begin{array}{l}\text { COVID-19 risk factors } \\
\text { correlated to FP ownership }\end{array}$ & $\begin{array}{l}\text { Evidence supporting correlation } \\
\text { between risk factor and FP ownership }\end{array}$ & Importance of risk factor \\
\hline Chain affiliation & $\begin{array}{l}\text { Research conducted in Connecticut }{ }^{14} \text {, } \\
\text { Canada (Ontario) }{ }^{46} \text {, and England }{ }^{34} \text { found } \\
\text { FP care homes to be more likely to be } \\
\text { affiliated to a chain. }\end{array}$ & $\begin{array}{l}\text { Of the } 18 \text { studies adjusting for chain } \\
\text { ownership, } 11 \text { found FP ownership } \\
\text { to exacerbate COVID-19 outcomes. }\end{array}$ \\
\hline Resident ethnicity & $\begin{array}{l}\text { A study using cumulative US state data } \\
\text { found that FP care homes serve a higher } \\
\text { proportion of ethnic minority residents }{ }^{39} \text {. }\end{array}$ & $\begin{array}{l}\text { Of the } 17 \text { studies that adjusted for } \\
\text { ethnicity, } 12 \text { found FP ownership to } \\
\text { exacerbate COVID-19 outcomes }\end{array}$ \\
\hline Older design standards & $\begin{array}{l}\text { A study conducted in Canada (Ontario) } \\
\text { found that outdated design standards were } \\
\text { more prevalent in FP care homes }{ }^{46} \text {. }\end{array}$ & $\begin{array}{l}\text { The one study adjusting for outdated } \\
\text { design standards did not find FP } \\
\text { ownership to be associated to } \\
\text { inferior COVID-19 outcomes. }\end{array}$ \\
\hline Crowding & $\begin{array}{l}\text { A study conducted in Canada (Ontario) }{ }^{31} \\
\text { found that FP care homes were more likely } \\
\text { to be crowded. }\end{array}$ & $\begin{array}{l}\text { The one study adjusting for } \\
\text { crowding found that both crowding } \\
\text { and FP ownership were statistically } \\
\text { significant risk factors. }\end{array}$ \\
\hline Staffing & $\begin{array}{l}\text { A study conducted in California }{ }^{50} \text { found FP } \\
\text { care homes to be associated with inferior } \\
\text { staffing conditions. }\end{array}$ & $\begin{array}{l}\text { Of the } 18 \text { studies adjusting for } \\
\text { staffing conditions, } 11 \text { found FP } \\
\text { ownership to exacerbate COVID-19 } \\
\text { outcomes. }\end{array}$ \\
\hline Quality & $\begin{array}{l}\text { Research conducted in West Virginia }{ }^{28} \text { and } \\
\text { California }{ }^{50} \text { found FP ownership to be } \\
\text { correlated with poor quality ratings. }\end{array}$ & $\begin{array}{l}\text { Of the } 18 \text { studies adjusting for } \\
\text { quality, } 10 \text { found FP ownership to } \\
\text { exacerbate COVID-19 outcomes. }\end{array}$ \\
\hline Union membership & $\begin{array}{l}\text { A study conducted in New York state found } \\
\text { that FP care homes were more likely to be } \\
\text { part of a union }{ }^{49} \text {. }\end{array}$ & $\begin{array}{l}\text { The one study adjusting for union } \\
\text { membership did not find FP } \\
\text { ownership to be associated to } \\
\text { inferior COVID-19 outcomes. }\end{array}$ \\
\hline Care home size & $\begin{array}{l}\text { Research conducted in Scotland }{ }^{53} \text { and } \\
\text { Connecticut }{ }^{14} \text { reported FP ownership to be } \\
\text { correlated to care home size. }\end{array}$ & $\begin{array}{l}\text { Of the } 25 \text { studies adjusting for care } \\
\text { home size, } 14 \text { found FP ownership } \\
\text { to exacerbate COVID-19 outcomes. }\end{array}$ \\
\hline
\end{tabular}

Note: This table only reports risk factors that were found to be significantly associated with FP ownership. Most studies which included the above mentioned risk factors as covariates did not report their correlation to FP ownership. See table A3 in the appendix for details on model adjustment and direction of effect. 
Table 3 provides an overview of the key risk factors that were correlated to FP ownership and how adjusting for these factors influenced the observed impact of FP ownership on COVID-19 outcomes. There was evidence to suggest that the effect of ownership was sensitive to certain model adjustments. For example, one Canadian study reported that the effect of FP ownership was mediated by care home characteristics, which was operationalised as older care home design standards, number of residents, staff to bed ratio, and chain affiliation. When including these covariates, the effect of FP ownership on COVID-19 mortality and incidence lost statistical significance. However, it was not clear from the analysis which of the included care home characteristics accounted for this change. Notably, a study conducted by the same team analysing data on the identical sample (long-term care homes in Ontario), time period (March 29 to May 20, 2020), and outcomes (outbreaks, incidence, and mortalities) accounted for different covariates and came to different conclusions ${ }^{31,46}$. Specifically, Stall et al ${ }^{46}$ did not find FP ownership to be a statistically significant predictor of COVID-19 mortality and incidence in their fully adjusted models, whereas Brown et $\mathrm{al}^{31}$, who adjusted for crowding instead of chain affiliation and outdated design standards, did report FP ownership to remain a statistically significant risk factor.

FP care homes were also more likely to be larger (in terms of number of clients) ${ }^{14}$, to serve minority groups ${ }^{39}$, to be more crowded ${ }^{31}$, and to have lower quality ratings ${ }^{28,50}$. This multicollinearity between ownership and important risk characteristics may account for a large part of the observed ownership effects. However, a substantial body of studies with low to moderate risk of bias found FP care home to perform worse during the pandemic, even when controlling for these characteristics. This consistent effect across country context and model specification suggests that there is a direct association between FP ownership and COVID-19 performance, independent of mediating variables, which is also consistent with previous research on care quality and FP ownership ${ }^{8,9}$.

\section{Discussion}

\section{Summary of findings}

Our synthesis and critical appraisal of 29 studies suggests that FP ownership is not consistently associated with a higher probability of COVID-19 outbreaks. Yet, there is compelling evidence suggesting that the consequences of outbreaks, in terms of cumulative infections and deaths, may be exacerbated by FP ownership. The finding that FP providers were consistently associated with PPE shortages, may help to explain why these care homes suffered from higher rates of infections and deaths following a COVID-19 outbreak during the early stages of the pandemic. However, there are important risk factors that may contribute to mediating this relationship, as FP care homes were often found to be associated to other important risk factors such as crowdedness ${ }^{31}$, client vulnerability ${ }^{39}$, and inferior quality ratings ${ }^{28,50}$.

Chain affiliated providers were often found to be correlated with higher risk of outbreak, but were not consistently associated with elevated numbers of infections. There was some evidence demonstrating a higher incidence of COVID-19 deaths among chain affiliated providers, particularly in Canada and England. Private-equity ownership was not consistently associated with inferior COVID-19 outcomes.

\section{Implications}

The findings of this review highlight the importance of ownership in accounting for poor COVID19 outcomes across care homes. It is known that the adult social care sector found itself exceedingly 
exposed in the beginning of the pandemic ${ }^{60}$, in large part due to delayed government support and intervention, but also as a result of many years of political and financial neglect ${ }^{11}$. With this review, we do not suggest that the challenges faced by care homes during the pandemic can (or should) be understood through the lens of ownership alone. It is clear that all care homes have faced severe challenges, which cannot be reduced to ownership. However, outsourcing to for-profit providers has become the status-quo in many care markets, often based on the rationale that open market competition will optimise the functioning of care homes. This claim has been extensively criticised and is not supported by empirical work ${ }^{6-9,61}$. This review adds to this evidence base by systematically appraising and synthesising the available research on how the consequences of the COVID-19 pandemic in care homes has varied by ownership during the first wave of the pandemic. Although our results represent multiple national settings, most of the included research was conducted in the US due to the availability of the national CMS dataset. Efforts are currently being made in the UK to create a similar type of systematic, live, and linked dataset on care homes ${ }^{62}$, which is an important endeavour if the consequences of this pandemic are to be understood and addressed going forward.

\section{Limitations}

Our findings should be interpreted in light of certain caveats, most of which relate to the characteristics of the included studies. First, most studies were conducted in the US and Canada and the results thus primarily relate to North America. Second, the majority of the US studies relied on CMS data, whereas all the Canadian studies were conducted in Ontario using the same sample of long term care facilities, which means that there may be overlap in the analysed data across certain studies. Although most studies investigated different outcomes and time periods, two Canadian studies analysed data covering the same sample, outcomes, and time interval ${ }^{31,46}$. Second, the body of included research was too heterogenous to be meaningfully meta-analysed and this version of the review thus represents a critical appraisal and narrative synthesis conducted in line with the SWiM and COSMOS-E guidance ${ }^{23,26}$. Third, throughout our risk of bias assessments, we assumed that the reporting of COVID-19 outcomes was not systematically related to ownership. However, there is some suggestive evidence of a longer turnaround period for resident test results among for-profit providers ${ }^{63}$, which if generally true, may bias the effect of FP ownership towards the null due to underreporting. Last, it is known that COVID-19 research is rapidly published ${ }^{19}$, which may expose our results to publication bias for articles that have been fast tracked for reporting timely and significant outcomes. However, by not restricting our studies to peer-reviewed research, we were able to also consider evidence presented in preprints and government reports in our synthesis.

\section{Conclusion and future research}

This review constitutes the first version of a living appraisal and synthesis of evidence on ownership variation across COVID-19 outcomes. It will be updated as new research becomes available, which may change the conclusion of our synthesis. Based on our synthesis of the available research, we find FP ownership to be a consistent and credible risk factor of higher cumulative COVID-19 infections and deaths in the first wave of the pandemic. Therefore, ownership and the characteristics associated with FP care home providers may present key regulatable factors that can be addressed to improve health outcomes in vulnerable populations and reduce health disparities. Going forward, we hope future research will incorporate other national contexts and clearly define their ownership categories of interest.

Contributors: ABM conceived the idea for the manuscript and designed the study protocol with feedback from BV and MDE. ABM and MDE double-screened and selected the included studies. ABM extracted and analysed all data with feedback from MDE and BV. AM validated all the extraction results. All authors contributed to quality assessing the 
included research in duplicate. MDE and ABM developed the visualisations for the paper. ABM wrote the manuscript with feedback from MDE, AM, and BV. The corresponding author attests that all listed authors meet authorship criteria and that no others meeting the criteria have been omitted.

Funding: Anders Bach-Mortensen is supported by a research fellowship from the Carlsberg Foundation. The funder was not involved in the research process.

\section{Competing interests: None.}

Ethical approval: Not applicable.

Data sharing: Most of the data represented is available in the manuscript or in the supplementary material. Additional data is available upon request. Our protocol is available online on Prospero (CRD42020218673) and on OSF (osf.io/c8dq9/). The authors affirm that this manuscript is an honest, accurate, and transparent account of the study being reported; that no important aspects of the study have been omitted; and that any discrepancies from the study as planned have been explained.

Dissemination to participants and related patient and public communities: Our protocol is available online on Prospero (CRD42020218673) and on OSF (osf.io/c8dq9/).

\section{References}

1. Oliver D. David Oliver: Let's be open and honest about covid-19 deaths in care homes. BMJ. 2020;369. doi:10.1136/bmj.m2334

2. Comas-Herrera A, Zalakain J. Mortality Associated with COVID-19 Outbreaks in Care Homes: Early International Evidence.; 2020.

3. Burki T. England and Wales see 20000 excess deaths in care homes. Lancet (London, England). 2020;395(10237):1602. doi:10.1016/S0140-6736(20)31199-5

4. Iacobucci G. Covid-19: Lack of PPE in care homes is risking spread of virus, leaders warn. BMJ. 2020;368. doi:http://dx.doi.org/10.1136/bmj.m1280

5. Le Grand J. Quasi-Markets and Social Policy. Econ J. 1991;101(September):1256-1267. doi:10.2307/2234441

6. Barron DN, West E. The quasi-market for adult residential care in the UK: Do for-profit, not-for-profit or public sector residential care and nursing homes provide better quality care? Soc Sci Med. 2017;179:137-146. doi:10.1016/j.socscimed.2017.02.037

7. Bach-Mortensen AM, Montgomery P. Does sector matter for the quality of care services? A secondary analysis of social care services regulated by the Care Inspectorate in Scotland. BMJ Open. 2019;9(2). doi:10.1136/bmjopen-2018-022975

8. Ronald LA, McGregor MJ, Harrington C, Pollock A, Lexchin J. Observational Evidence of For-Profit Delivery and Inferior Nursing Home Care: When Is There Enough Evidence for Policy Change? PLoS Med. 2016;13(4). doi:10.1371/journal.pmed.1001995

9. Comondore VR, Devereaux PJ, Zhou Q, et al. Quality of care in for-profit and not-for-profit nursing homes: Systematic review and meta-analysis. BMJ. 2009;339(7717):381-384. doi:10.1136/bmj.b2732

10. Stolt R, Blomqvist P, Winblad U. Privatization of social services: Quality differences in Swedish elderly care. Soc Sci Med. 2011;72(4):560-567.

doi:10.1016/J.SOCSCIMED.2010.11.012

11. O'Neill D. Covid-19 in care homes: The many determinants of this perfect storm. BMJ. 2020;369. doi:10.1136/bmj.m2096

12. Covid-19 outbreaks up to 20 times more likely in large care homes, study finds | World news | The Guardian. The Guardian. https://www.theguardian.com/world/2020/jul/14/covid-19outbreaks-up-to-20-times-more-likely-in-large-care-homes-uk-study. Published 2020. 
Accessed November 13, 2020.

13. Push for Profits Leaves Nursing Homes Struggling to Provide Care During Coronavirus Pandemic - The New York Times. New York Times. https://www.nytimes.com/2020/05/07/business/coronavirus-nursing-homes.html. Published 2020. Accessed November 13, 2020.

14. Li Y, Temkin-Greener H, Gao S, Cai X. COVID-19 infections and deaths among Connecticut nursing home residents: facility correlates. J Am Geriatr Soc. June 2020. doi:http://dx.doi.org/10.1111/jgs.16689

15. Rolland Y, Lacoste MH, De Mauleon A, et al. Guidance for the Prevention of the COVID19 Epidemic in Long-Term Care Facilities: A Short-Term Prospective Study. J Nutr Heal Aging. 2020;24(8):812-816. doi:10.1007/s12603-020-1440-2

16. Glasby J, Zhang Y, Bennett MR, Hall P. A lost decade? A renewed case for adult social care reform in England. J Soc Policy. 2020:1 -32. doi:10.1017/s0047279420000288

17. Oliver D. David Oliver: Let's not forget care homes when covid-19 is over. BMJ. 2020;369. doi:10.1136/bmj.m1629

18. OSF | Ownership and COVID-19 in residential care facilities for the elderly: A living systematic review of outbreaks and mortalities. https://osf.io/c8dq9/. Accessed December 10, 2020.

19. Palayew A, Norgaard O, Safreed-Harmon K, Andersen TH, Rasmussen LN, Lazarus J V. Pandemic publishing poses a new COVID-19 challenge. Nat Hum Behav. 2020;4(7):666-669. doi:10.1038/s41562-020-0911-0

20. Elliott JH, Synnot A, Turner T, et al. Living systematic review: 1. Introduction - the why, what, when, and how. J Clin Epidemiol. 2017;91:23-30. doi:10.1016/j.jclinepi.2017.08.010

21. Elliott JH, Turner T, Clavisi O, et al. Living Systematic Reviews: An Emerging Opportunity to Narrow the Evidence-Practice Gap. PLoS Med. 2014;11(2):1-6.

doi:10.1371/journal.pmed.1001603

22. Moher D, Liberati A, Tetzlaff J, Altman DG. Preferred reporting items for systematic reviews and meta-analyses: The PRISMA statement. Int J Surg. 2010;8(5):336-341.

doi:10.1016/j.ijsu.2010.02.007

23. Dekkers Id OM, Vandenbroucke JP, Cevallos M, Renehanid AG, Altman DG, Eggerid M. COSMOS-E: Guidance on conducting systematic reviews and meta-analyses of observational studies of etiology. 2019. doi:10.1371/journal.pmed.1002742

24. Sterne JA, Hernán MA, Reeves BC, et al. ROBINS-I: A tool for assessing risk of bias in nonrandomised studies of interventions. BMJ. 2016;355:4-10. doi:10.1136/bmj.i4919

25. Mueller M, D'Addario M, Egger M, et al. Methods to systematically review and meta-analyse observational studies: A systematic scoping review of recommendations. BMC Med Res Methodol. 2018;18(1):1-18. doi:10.1186/s12874-018-0495-9

26. Campbell M, McKenzie JE, Sowden A, et al. Synthesis without meta-analysis (SWiM) in systematic reviews: Reporting guideline. BMJ. 2020;368. doi:10.1136/bmj.16890

27. Ogilvie D, Fayter D, Petticrew M, et al. The harvest plot: A method for synthesising evidence about the differential effects of interventions. BMC Med Res Methodol. 2008;8. doi:10.1186/1471-2288-8-8

28. Bui DP, See MD I, Hesse MD EM, et al. Association Between CMS Quality Ratings and COVID19 Outbreaks in Nursing Homes - West Virginia, March 17-June 11, 2020. Atlanta: U.S. Center for Disease Control; 2020. https://www.cdc.gov/mmwr/volumes/69/wr/mm6937a5.htm.

29. Rowan P, Rebecca Lester P, Michael Levere B, Libersky J, Debra Lipson M, Julie Robison M. A Study of the COVID-19 Outbreak and Response in Connecticut Long-Term Care Facilities Interim 
Report:; 2020.

30. Unruh MA, Yun H, Zhang Y, Braun RT, Jung HY. Nursing Home Characteristics Associated With COVID-19 Deaths in Connecticut, New Jersey, and New York. J Am Med Dir Assoc. 2020;21(7):1001-1003. doi:10.1016/j.jamda.2020.06.019

31. Brown K, Jones A, Daneman N, et al. Association Between Nursing Home Crowding and COVID-19 Infection and Mortality in Ontario, Canada. Jama Intern Med. 2020:1-8. doi:10.1101/2020.06.23.20137729

32. Bowblis J, Applebaum R. Prevalence of COVID-19 in Ohio Nursing Homes: What's Quality Got to Do with It? J Aging Soc Policy. 2020;00(00):1-17. doi:10.1080/08959420.2020.1824542

33. McGarry BE, Grabowski DC, Barnett ML. Severe Staffing And Personal Protective Equipment Shortages Faced By Nursing Homes During The COVID-19 Pandemic. Health Aff. 2020;39(10):1812-1821,1821A-1821I. doi:http://dx.doi.org/10.1377/hlthaff.2020.01269

34. Morciano M, Stokes JM, Kontopantelis E, Hall I, Turner AJ. Excess mortality for care home residents during the first 23 weeks of the COVID-19 pandemic in England a national cohort study. medRxiv. 2020. https://medrxiv.org/cgi/content/short/2020.11.11.20229815.

35. Braun RT, Yun H, Casalino LP, et al. Comparative Performance of Private Equity-Owned US Nursing Homes During the COVID-19 Pandemic. JAMA Netw open.

2020;3(10):e2026702. doi:10.1001/jamanetworkopen.2020.26702

36. Gandhi A, Song Y, Upadrashta P. Have Private Equity Owned Nursing Homes Fared Worse Under COVID-19? SSRN Electron J. 2020. doi:10.2139/ssrn.3682892

37. Xu H, Intrator O, Bowblis JR. Shortages of Staff in Nursing Homes During the COVID-19 Pandemic: What are the Driving Factors? J Am Med Dir Assoc. 2020;21(10):1371-1377. doi:10.1016/j.jamda.2020.08.002

38. Gibson DM, Greene J. State Actions and Shortages of Personal Protective Equipment and Staff in U.S. Nursing Homes. J Am Geriatr Soc. 2020:1-6. doi:10.1111/jgs.16883

39. Li Y, Cen X, Cai X, Temkin-Greener H. Racial and Ethnic Disparities in COVID-19 Infections and Deaths Across U.S. Nursing Homes. J Am Geriatr Soc. 2020:1-8. doi:10.1111/jgs.16847

40. Gopal R, Han X, Yaraghi N. Compress the curve: A cross-sectional study of variations in COVID-19 infections across California nursing homes. BMJ Open. 2021;11(1). doi:10.1136/bmjopen-2020-042804

41. Shallcross L, Burke D, Stat OAC, et al. Risk factors associated with SARS-CoV-2 infection and outbreaks in Long Term Care Facilities in England: A national survey. Lancet Heal Longev. February 2021. doi:10.1101/2020.10.02.20205591

42. Chen MK, Chevalier JA, Long EF. Nursing home staff networks and COVID-19. Proc Natl Acad Sci. 2020;118(1). doi:10.3386/w27608

43. Chatterjee P, Kelly S, Qi M, Werner RM. Characteristics and Quality of US Nursing Homes Reporting Cases of Coronavirus Disease 2019 (COVID-19). JAMA Netw open. 2020;3(7):e2016930. doi:10.1001/jamanetworkopen.2020.16930

44. Abrams HR, Loomer L, Gandhi A, Grabowski DC. Characteristics of U.S. Nursing Homes with COVID-19 Cases. J Am Geriatr Soc. June 2020. doi:http:/ /dx.doi.org/10.1111/jgs.16661

45. Li Y, Fang F, He M. Exploring the N95 and Surgical Mask Supply in U.S. Nursing Homes During COVID-19. J Appl Gerontol. 2020:733464820969015. doi:10.1177/0733464820969015

46. Stall NM, Jones A, Brown KA, Rochon PA, Costa AP. For-profit long-term care homes and the risk of COVID-19 outbreaks and resident deaths. Cmaj. 2020;192(33):E946-E955. doi:10.1503/cmaj.201197

47. He M, Li Y, Fang F. Is There a Link between Nursing Home Reported Quality and COVID- 
19 Cases? Evidence from California Skilled Nursing Facilities. J Am Med Dir Assoc. 2020;21(7):905-908. doi:10.1016/j.jamda.2020.06.016

48. Sugg MM, Spaulding TJ, Lane SJ, et al. Mapping community-level determinants of COVID19 transmission in nursing homes: A multi-scale approach. Sci Total Environ. 2021;752:141946. doi:10.1016/j.scitotenv.2020.141946

49. Dean A, Venkataramani A, Kimmel S. Mortality Rates From COVID-19 Are Lower In Unionized Nursing Homes. Health Aff. 2020:10.1377/hlthaff. doi:10.1377/hlthaff.2020.01011

50. Harrington C, Ross L, Chapman S, Halifax E, Spurlock B, Debra B. Nurse Staffing and Coronavirus Infections in California Nursing Homes. Policy Polit Nurs Pract. 2020;21(3):174186. doi:http://dx.doi.org/10.1177/1527154420938707

51. Fisman DN, Bogoch I, Lapointe-Shaw L, McCready J, Tuite AR. Risk Factors Associated With Mortality Among Residents With Coronavirus Disease 2019 (COVID-19) in Long-term Care Facilities in Ontario, Canada. JAMA Netw open. 2020;3(7):e2015957. doi:10.1001/jamanetworkopen.2020.15957

52. Gorges RJ, Konetzka RT. Staffing Levels and COVID-19 Cases and Outbreaks in U.S. Nursing Homes. J Am Geriatr Soc. 2020:1-5. doi:10.1111/jgs.16787

53. Burton J, Bayne G, Evans C, et al. Evolution and impact of COVID-19 outbreaks in care homes: population analysis in 189 care homes in one geographic region. Lancet Heal Longev. 2020;1(1):e21-e31. doi:10.1101/2020.07.09.20149583

54. Shen K. Relationship between nursing home COVID-19 outbreaks and staff neighborhood characteristics. medRxiv. 2020;3:2020.09.10.20192203.

https://www.medrxiv.org/content/10.1101/2020.09.10.20192203v1\%0Ahttps://www.medr xiv.org/content/10.1101/2020.09.10.20192203v1.abstract.

55. Centers for Medicaid and Medicare Services. Interim Final Rule Updating Requirements for Notification of Confirmed and Suspected COVID-19 Cases Among Residents and Staff in Nursing Homes.; 2020. https://nhsn.cdc.gov/RegistrationForm/index. Accessed November 18, 2020.

56. Finch WH, Hernández Finch ME. Poverty and Covid-19: Rates of Incidence and Deaths in the United States During the First 10 Weeks of the Pandemic. Front Sociol. 2020;5:47. doi:10.3389/fsoc.2020.00047

57. Patel P, Hiam L, Sowemimo A, Devakumar D, McKee M. Ethnicity and covid-19. BMJ. 2020;369. doi:10.1136/bmj.m2282

58. Panagiotou OA, Kosar CM, White EM, et al. Risk Factors Associated with All-Cause 30-Day Mortality in Nursing Home Residents with COVID-19. JAMA Intern Med. 2021. doi:10.1001/jamainternmed.2020.7968

59. Bach-Mortensen AM, Degli Esposti M. Is area deprivation associated with greater impacts of COVID-19 in care homes across England? A preliminary analysis of COVID-19 outbreaks and deaths. J Epidemiol Community Health. 2021:1-4. doi:10.1136/jech-2020-215039

60. Ouslander JG, Grabowski DC. COVID-19 in Nursing Homes: Calming the Perfect Storm. J Am Geriatr Soc. July 2020. doi:http://dx.doi.org/10.1111/jgs.16784

61. Ben-Ner A, Karaca-Mandic P, Ren T. Ownership and quality in markets with asymmetric information: Evidence from nursing homes. BE J Econ Anal Policy. 2012;12(1):42. doi:10.1515/1935-1682.3038

62. Hanratty B, Burton JK, Goodman C, Gordon AL, Spilsbury K. Covid-19 and lack of linked datasets for care homes: The pandemic has shed harsh light on the need for a live minimum dataset. BMJ. 2020;369. doi:10.1136/bmj.m2463

63. Mcgarry BE, Steelfisher GK, Grabowski DC, Barnett ML. COVID-19 Test Result Turnaround Time for Residents and Staff in US Nursing Homes. JAMA Intern Med. 
medRxiv preprint doi: https://doi.org/10.1101/2021.01.28.21250547; this version posted February 23, 2021. The copyright holder for this preprint (which was not certified by peer review) is the author/funder, who has granted medRxiv a license to display the preprint in perpetuity. It is made available under a CC-BY-NC-ND 4.0 International license .

2020;(July):5-7. doi:10.1001/jamainternmed.2020.7330 


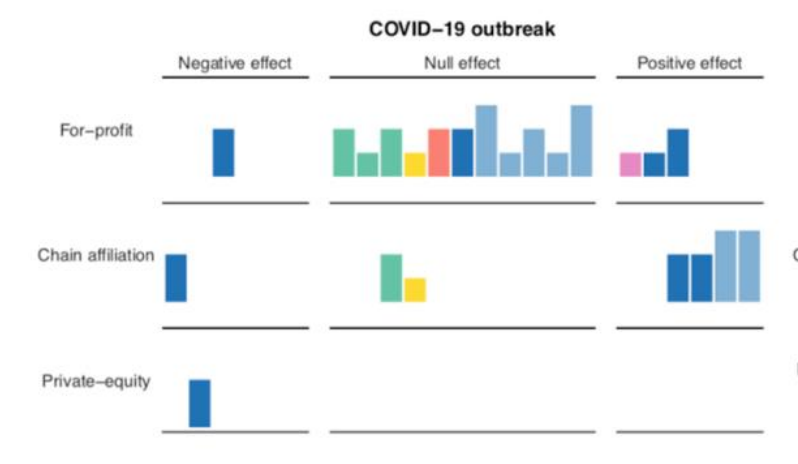

Personal Protective Equipment Negative effect Null effect Positive effect

For-profit

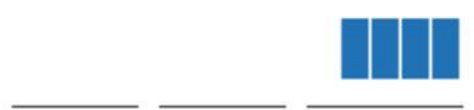

Chain attriation

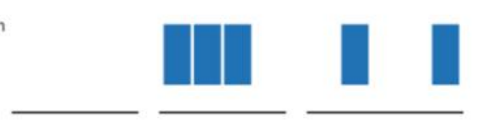

Private-equity

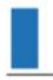

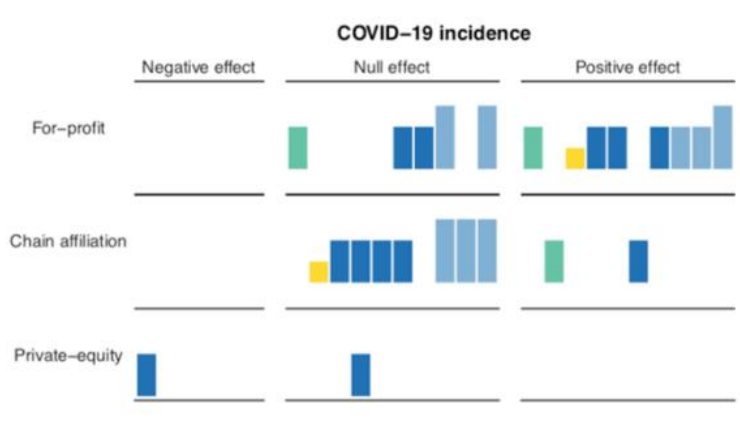

Negative effect Null effect Positive effect
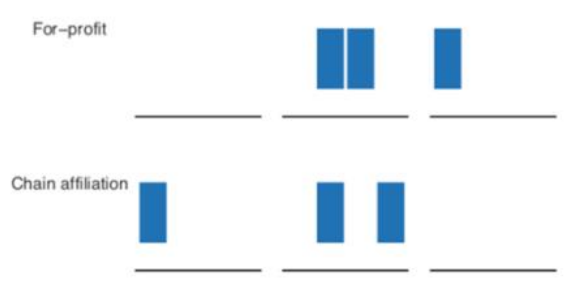

Private-equity

Figure 2: Harvest plot on the direction of effect across ownership, risk of bias, and study context. Bar height indicates overall risk of bias and colour denotes study context. Positive and negative effects are understood as associations in either direction that are statistically significant at the $5 \%$ level. Note that positive effects refer to elevated COVID-19 outcome values. Null effect is understood as differences that are not statistically significant at the $5 \%$ level. Outbreaks usually refer to the presence of any COVID-19 infections, except for one study that defined outbreaks as at least two cases ${ }^{28}$. COVID-19 incidence usually refers to the cumulative number of COVID-19 infections, but also includes binary outcomes on large outbreaks (e.g. ${ }^{41,52}$ ). COVID-19 mortality usually refers to cumulative cases, except for one study which used a binary indicator of at least 6 deaths ${ }^{30}$, and another which analysed a dichotomised outcome of any number of deaths vs no deaths 34 


\section{Supplementary Material}

Table A1: Ownership categorisation and overlap.

\begin{tabular}{|c|c|c|}
\hline Ownership categories & Definition & Potential overlap \\
\hline For-profit & $\begin{array}{l}\text { Private profit pursuing providers of } \\
\text { social care. This usually includes both } \\
\text { individually owned, partnerships, and } \\
\text { corporate providers. }\end{array}$ & $\begin{array}{l}\text { This term may include chain affiliated } \\
\text { and private equity owned providers. } \\
\text { For-profits and non-profit providers are } \\
\text { sometimes categorised as private } \\
\text { providers. }\end{array}$ \\
\hline Non-profit & $\begin{array}{l}\text { Private not-for-profit providers of social } \\
\text { care. These providers are usually } \\
\text { registered as charities. }\end{array}$ & $\begin{array}{l}\text { This term may include chain affiliated } \\
\text { providers. For-profits and non-profit } \\
\text { providers are sometimes categorised as } \\
\text { private providers. }\end{array}$ \\
\hline Public & $\begin{array}{l}\text { Care providers operated and organised } \\
\text { by government bodies and employees. } \\
\text { These providers are usually operated at } \\
\text { the municipal, council, or local authority } \\
\text { level. }\end{array}$ & $\begin{array}{l}\text { Public and non-profit providers are } \\
\text { often categorised as not-for-profit } \\
\text { providers. }\end{array}$ \\
\hline Private & $\begin{array}{l}\text { Providers that are privately owned, } \\
\text { including both for-profit and non-profit } \\
\text { providers. }\end{array}$ & $\begin{array}{l}\text { This may include for-profit, non-profit, } \\
\text { chain affiliated, and private equity } \\
\text { providers. }\end{array}$ \\
\hline Multifacility chain affiliation & $\begin{array}{l}\text { Providers that are part of a multi-location } \\
\text { chain of social care facilities. }\end{array}$ & $\begin{array}{l}\text { This may include both for-profit, } \\
\text { private equity, and non-profit } \\
\text { providers. }\end{array}$ \\
\hline Private equity owned & $\begin{array}{l}\text { Providers that have been acquisitioned by } \\
\text { private equity firms. }\end{array}$ & $\begin{array}{l}\text { This may include for-profit and chain } \\
\text { affiliated providers. }\end{array}$ \\
\hline
\end{tabular}


Table A2: Data sources and time period for COVID-19 outcomes.

\begin{tabular}{|c|c|c|c|}
\hline Study & $\begin{array}{c}\text { Time period for COVID-19 } \\
\text { outcomes }\end{array}$ & Data source & $\begin{array}{l}\text { Confirmed or self- } \\
\text { reported outcomes }\end{array}$ \\
\hline 1 & March 17 to June 11, 2020 & $\begin{array}{l}\text { West Virginia Department of Health } \\
\text { and Human Resources }\end{array}$ & Confirmed \\
\hline 2 & April 22 to April 29, 2020 & Cumulative state data & $\begin{array}{l}\text { Self-report (confirmed } \\
\text { and suspected) }\end{array}$ \\
\hline 3 & As of May 11, 2020 & Cumulative state data & $\begin{array}{l}\text { Self-report (confirmed } \\
\text { and suspected) }\end{array}$ \\
\hline 4 & May 17 to July 2, 2020 & CMS data & $\begin{array}{l}\text { Self-report (confirmed } \\
\text { and suspected) }\end{array}$ \\
\hline 5 & As of April 16, 2020 & $\begin{array}{l}\text { Connecticut Department of Health and } \\
\text { Human Services }\end{array}$ & Confirmed \\
\hline 6 & Week ending June 21, 2020 & CMS data & $\begin{array}{l}\text { Self-report (confirmed } \\
\text { and suspected) }\end{array}$ \\
\hline 7 & March 29 to May 20, 2020 & $\begin{array}{l}\text { Ontario Ministry of Health and Long- } \\
\text { term Care }\end{array}$ & Confirmed \\
\hline 8 & April 23 to June 2,2020 & $\begin{array}{l}\text { California Department of Public Health } \\
\text { (California SNFs COVID-19 data) }\end{array}$ & Confirmed \\
\hline 9 & As of June 302020 & CMS data & $\begin{array}{l}\text { Self-report (confirmed } \\
\text { and suspected) }\end{array}$ \\
\hline 10 & As of May 31st 2020 & New York State Department of Health & Confirmed \\
\hline 11 & March to May 4, 2020 & $\begin{array}{l}\text { California and Los Angeles } \\
\text { Departments of Public Health }\end{array}$ & $\begin{array}{l}\text { Self-report (confirmed } \\
\text { and suspected) }\end{array}$ \\
\hline 12 & $\begin{array}{l}\text { Connecticut: As of April } 16 \\
\text { New York: As of April } 15 \\
\text { New Jersey: As of April } 20\end{array}$ & $\begin{array}{l}\text { State data from Connecticut, New } \\
\text { Jersey, and New York. }\end{array}$ & Unclear \\
\hline 13 & $\begin{array}{l}\text { Weekly reports on April } 28 \text {, May } \\
14 \text {, and June } 17 \text { - all recorded } \\
\text { from April } 15,2020\end{array}$ & Ohio Department of Health & Confirmed \\
\hline 14 & May 25 to May 31, 2020 & CMS data & $\begin{array}{l}\text { Self-report (confirmed } \\
\text { and suspected) }\end{array}$ \\
\hline 15 & March 3 to April 11, 2020 & $\begin{array}{l}\text { Ontario Ministry of Health and Long- } \\
\text { term Care }\end{array}$ & Confirmed \\
\hline 16 & The week of May 31, 2020 & CMS data & $\begin{array}{l}\text { Self-report (confirmed } \\
\text { and suspected) }\end{array}$ \\
\hline 17 & As of June 25, 2020 & CMS data & $\begin{array}{l}\text { Self-report (confirmed } \\
\text { and suspected) }\end{array}$ \\
\hline
\end{tabular}




\begin{tabular}{|c|c|c|c|}
\hline 18 & $\begin{array}{l}\text { May } 18 \text { to June } 14,2020 \text { (study } \\
\text { period } 1 \text { ) and June } 24 \text { to July } 19, \\
2020 \text { (study period 2). }\end{array}$ & CMS data & $\begin{array}{l}\text { Self-report (confirmed } \\
\text { and suspected) }\end{array}$ \\
\hline 19 & $\begin{array}{l}\text { Week ending June } 21 \text {, to the week } \\
\text { ending July 19, } 2020\end{array}$ & CMS data & $\begin{array}{l}\text { Self-report (confirmed } \\
\text { and suspected) }\end{array}$ \\
\hline 20 & As of July 22,2020 & $\begin{array}{l}\text { Connecticut Department of Health and } \\
\text { Human Services }\end{array}$ & $\begin{array}{l}\text { Self-report (confirmed } \\
\text { and suspected) }\end{array}$ \\
\hline 21 & March 29 to May 20, 2020 & $\begin{array}{l}\text { Ontario Ministry of Health and Long- } \\
\text { term Care }\end{array}$ & $\begin{array}{l}\text { Self-report (confirmed } \\
\text { and suspected) }\end{array}$ \\
\hline 22 & March 1 to August 2, 2020 & Care Inspectorate & Confirmed \\
\hline 23 & May 6 to 7 October, 2020 & Cumulative state data & $\begin{array}{l}\text { Self-report (confirmed } \\
\text { and suspected) }\end{array}$ \\
\hline 24 & As of May 31, 2020 & Cumulative state data & $\begin{array}{l}\text { Self-report (confirmed } \\
\text { and suspected) }\end{array}$ \\
\hline 25 & Week ending May 24, 2020 & CMS data & $\begin{array}{l}\text { Self-report (confirmed } \\
\text { and suspected) }\end{array}$ \\
\hline 26 & April 30 to 13 June, 2020 & $\begin{array}{l}\text { Unique data collected for the study } \\
\text { (conducted by Ipsos MORI) }\end{array}$ & Confirmed \\
\hline 27 & March 23rd to May $6^{\text {th }}, 2020$ & Survey data collected for this paper & $\begin{array}{l}\text { Self-report (confirmed } \\
\text { and suspected) }\end{array}$ \\
\hline 28 & March 4 to August 7, 2020 & Care Quality Commission & $\begin{array}{l}\text { Self-report (confirmed } \\
\text { and suspected) }\end{array}$ \\
\hline 29 & As of $1^{\text {st }}$ May, 2020 & California Department of Public Health & Confirmed \\
\hline
\end{tabular}


Table A3: Risk of bias assessments using COSMOS-E guidance.

\begin{tabular}{|c|c|c|c|}
\hline \multirow[t]{2}{*}{ Study } & \multicolumn{3}{|c|}{ Risk of bias } \\
\hline & Confounding bias & Selection bias & Information bias \\
\hline (Bui et al., 2020) 25 & High & Low & Low \\
\hline $\begin{array}{l}\text { (Chatterjee, Kelly, Qi, \& } \\
\text { Werner, 2020) }{ }^{40}\end{array}$ & High & Low & Low \\
\hline $\begin{array}{l}\text { (Abrams, Loomer, Gandhi, \& } \\
\text { Grabowski, 2020) }{ }^{41}\end{array}$ & Moderate & Moderate & Moderate \\
\hline (Braun et al., 2020) ${ }^{32}$ & Low & Moderate & Low \\
\hline $\begin{array}{l}\text { (Yue Li, Temkin-Greener, Gao, } \\
\text { \& Cai, 2020) }{ }^{14}\end{array}$ & Low & Low & Low \\
\hline $\begin{array}{l}\text { (Yumeng Li, Fang, \& He, 2020) } \\
42\end{array}$ & Low & Moderate & Low \\
\hline $\begin{array}{l}\text { (Stall, Jones, Brown, Rochon, \& } \\
\text { Costa, 2020) } 43\end{array}$ & Moderate & Moderate & Low \\
\hline (He, Li, \& Fang, 2020) 44 & Moderate & Low & Low \\
\hline (Sugg et al., 2021) 45 & Moderate & Moderate & Low \\
\hline $\begin{array}{l}\text { (Dean, Venkataramani, \& } \\
\text { Kimmel, 2020) } 46\end{array}$ & Low & Moderate & Low \\
\hline (Harrington et al., 2020) 47 & Moderate & High & Low \\
\hline $\begin{array}{l}\text { (Unruh, Yun, Zhang, Braun, \& } \\
\text { Jung, 2020) } 27\end{array}$ & Moderate & Low & Low \\
\hline (Bowblis \& Applebaum, 2020) & Low & Low & Low \\
\hline $\begin{array}{l}\text { (Yue Li, Cen, Cai, \& Temkin- } \\
\text { Greener, 2020) } 36\end{array}$ & Low & Moderate & Low \\
\hline $\begin{array}{l}\text { (Fisman, Bogoch, Lapointe- } \\
\text { Shaw, McCready, \& Tuite, } \\
\text { 2020) } 48\end{array}$ & High & Low & Low \\
\hline $\begin{array}{l}\text { Xu, Intrator, \& Bowblis, 2020) } \\
34\end{array}$ & Low & Moderate & Low \\
\hline (Gorges \& Konetzka, 2020) ${ }^{49}$ & Low & Moderate & Low \\
\hline $\begin{array}{l}\text { (McGarry, Grabowski, \& } \\
\text { Barnett, 2020) }\end{array}$ & Low & Moderate & Low \\
\hline (Gibson \& Greene, 2020) 35 & Low & Moderate & Low \\
\hline (Rowan et al., 2020) 26 & Low & Low & Low \\
\hline (Brown et al., 2020) ${ }^{28}$ & Moderate & Moderate & Low \\
\hline (Burton et al., 2020) 50 & Moderate & Low & Low \\
\hline
\end{tabular}




\begin{tabular}{|c|c|c|c|}
\hline (Shen, 2020) ${ }^{51}$ & Low & Moderate & Low \\
\hline $\begin{array}{l}\text { (Chen, Chevalier, \& Long, } \\
\text { 2020) } 39\end{array}$ & Low & Moderate & Low \\
\hline $\begin{array}{l}\text { (Gandhi, Song, \& Upadrashta, } \\
2020)^{33}\end{array}$ & Low & Moderate & Low \\
\hline (Shallcross et al., 2020) 38 & Low & High & Moderate \\
\hline (Rolland et al., 2020) ${ }^{15}$ & High & Moderate & Moderate \\
\hline $\begin{array}{l}\text { (Morciano, Stokes, } \\
\text { Kontopantelis, Hall, \& Turner, } \\
\text { 2020) }\end{array}$ & Moderate & Low & Low \\
\hline $\begin{array}{l}\text { (Gopal, Han, \& Yaraghi, 2021) } \\
37\end{array}$ & Moderate & Moderate & Moderate \\
\hline
\end{tabular}


Table A4: Adjustments and direction of effect.

\begin{tabular}{|c|c|c|c|c|c|c|c|c|c|c|c|c|}
\hline \multirow[b]{2}{*}{ Study } & \multicolumn{8}{|c|}{ Covariates adjusted for } & \multicolumn{4}{|c|}{ Outcomes } \\
\hline & Size & $\begin{array}{l}\text { Urban/rural or } \\
\text { population density }\end{array}$ & $\begin{array}{l}\text { Quality } \\
\text { ratings }\end{array}$ & Staffing & $\begin{array}{l}\text { Local incidence } \\
\text { of cases }\end{array}$ & Ethnicity & $\begin{array}{l}\text { Resident } \\
\text { SES }\end{array}$ & Covid-19 outbreak & $\begin{array}{l}\text { Covid-19 } \\
\text { deaths }\end{array}$ & $\begin{array}{l}\text { Covid-19 } \\
\text { incidence }\end{array}$ & PPE & $\begin{array}{l}\text { Staffing } \\
\text { shortage }\end{array}$ \\
\hline \multirow{2}{*}{\multicolumn{13}{|c|}{ For-profit ownership }} \\
\hline & & & & & & & & & & & & \\
\hline 2 & & & & & & & & $\mathrm{X}$ & & & & \\
\hline 3 & $\mathrm{X}$ & $\mathrm{X}$ & $\mathrm{X}$ & & $\mathrm{X}$ & $\mathrm{X}$ & $\mathrm{X}$ & $\mathrm{x}$ & & $\mathrm{X}$ & & \\
\hline 5 & $\mathrm{X}$ & & $\mathrm{X}$ & $\mathrm{X}$ & & $\mathrm{X}$ & $\mathrm{X}$ & & $\mathrm{X}$ & $\mathrm{X}$ & & \\
\hline 6 & $\mathrm{X}$ & $\mathrm{X}$ & & $\mathrm{X}$ & $\mathrm{X}$ & $\mathrm{X}$ & $\mathrm{X}$ & & & & $\mathrm{x}$ & \\
\hline 7 & $\mathrm{X}$ & & & $\mathrm{X}$ & $\mathrm{X}$ & & & $\mathrm{X}$ & $\mathrm{X}$ & $\mathrm{X}$ & & \\
\hline 8 & $\mathrm{X}$ & & $\mathrm{X}$ & & & $\mathrm{X}$ & & & $\mathrm{X}$ & $\mathrm{X}$ & & \\
\hline 9 & $\mathrm{X}$ & $\mathrm{X}$ & $\mathrm{X}$ & $\mathrm{X}$ & & $\mathrm{X}$ & & & 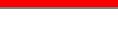 & $\mathrm{X}$ & & \\
\hline 10 & $\mathrm{X}$ & & $\mathrm{X}$ & $\mathrm{X}$ & $\mathrm{X}$ & $\mathrm{X}$ & $\mathrm{X}$ & & $\mathrm{X}$ & & & \\
\hline 11 & $\mathrm{X}$ & & $\mathrm{X}$ & $\mathrm{X}$ & & & & $\mathrm{X}$ & & & & \\
\hline 12 & $\mathrm{X}$ & & & $\mathrm{X}$ & & $\mathrm{X}$ & $\mathrm{X}$ & & $\mathrm{X}$ & & & \\
\hline 13 & $\mathrm{X}$ & $\mathrm{X}$ & $\mathrm{X}$ & $\mathrm{X}$ & & $\mathrm{X}$ & $\mathrm{X}$ & $\mathrm{X}$ & & $\mathrm{X}$ & & \\
\hline 14 & $\mathrm{X}$ & & $\mathrm{X}$ & $\mathrm{X}$ & $\mathrm{X}$ & $\mathrm{X}$ & $\mathrm{X}$ & & $\mathrm{X}$ & $\mathrm{X}$ & & \\
\hline 15 & & & & & & & & $\mathrm{X}$ & & & & \\
\hline 16 & $\mathrm{X}$ & $\mathrm{X}$ & $\mathrm{X}$ & $\mathrm{X}$ & & & $\mathrm{X}$ & & & & & $\mathrm{X}$ \\
\hline 17 & $\mathrm{X}$ & & & $\mathrm{X}$ & $\mathrm{X}$ & $\mathrm{X}$ & $\mathrm{X}$ & $\mathrm{X}$ & $\mathrm{X}$ & $\mathrm{X}$ & & \\
\hline 18 & $\mathrm{X}$ & & $\mathrm{X}$ & $\mathrm{X}$ & $\mathrm{X}$ & $\mathrm{X}$ & $\mathrm{X}$ & & & & $\mathrm{X}$ & $\mathrm{X}$ \\
\hline 19 & $\mathrm{X}$ & $\mathrm{X}$ & $\mathrm{X}$ & $\mathrm{X}$ & $\mathrm{X}$ & $\mathrm{X}$ & $\mathrm{X}$ & & & & $\mathrm{X}$ & $\mathrm{X}$ \\
\hline 20 & $\mathrm{X}$ & & $\mathrm{X}$ & $\mathrm{X}$ & $\mathrm{X}$ & $\mathrm{X}$ & & $\mathrm{X}$ & $\mathrm{X}$ & $\mathrm{X}$ & & \\
\hline 21 & $\mathrm{X}$ & $\mathrm{X}$ & & & $\mathrm{X}$ & $\mathrm{X}$ & & $\mathrm{X}$ & $\mathrm{X}$ & $\mathrm{X}$ & & \\
\hline 22 & $\mathrm{X}$ & & $\mathrm{X}$ & & $\mathrm{X}$ & & & $\mathrm{X}$ & 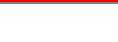 & . & & \\
\hline 23 & $\mathrm{X}$ & $\mathrm{X}$ & $\mathrm{X}$ & $\mathrm{X}$ & $\mathrm{X}$ & $\mathrm{X}$ & $\mathrm{X}$ & & $\mathrm{X}$ & - & & \\
\hline 24 & $\mathrm{X}$ & $\mathrm{X}$ & $\mathrm{X}$ & & $\mathrm{X}$ & $\mathrm{X}$ & $\mathrm{X}$ & & 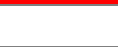 & $\mathrm{X}$ & & \\
\hline 25 & $\mathrm{X}$ & $\mathrm{X}$ & & & $\mathrm{X}$ & $\mathrm{X}$ & $\mathrm{X}$ & $\mathrm{X}$ & $\mathrm{X}$ & $\mathrm{X}$ & $\mathrm{X}$ & \\
\hline 26 & $\mathrm{X}$ & & $\mathrm{X}$ & $\mathrm{X}$ & $\mathrm{X}$ & & $\mathrm{X}$ & $\mathrm{X}$ & & X & & \\
\hline 27 & & & $\mathrm{X}$ & $\mathrm{X}$ & & & & $\mathrm{X}$ & & & & \\
\hline 28 & $\mathrm{X}$ & $\mathrm{X}$ & & & $\mathrm{X}$ & & & & $\mathrm{x}$ & & & \\
\hline 29 & $\mathrm{X}$ & & $\mathrm{X}$ & $\mathrm{X}$ & $\mathrm{X}$ & & & $\mathrm{X}$ & & $\mathrm{X}$ & & \\
\hline & & & & & & Chain & liation & & & & & \\
\hline 3 & $\mathrm{X}$ & $\mathrm{X}$ & $\mathrm{X}$ & & $\mathrm{X}$ & $\mathrm{X}$ & $\mathrm{X}$ & $\mathrm{X}$ & & $\mathrm{X}$ & & \\
\hline 4 & $\mathrm{X}$ & $X$ & & & & $\mathrm{X}$ & $\mathrm{X}$ & & $\mathrm{X}$ & $\mathrm{X}$ & & \\
\hline 5 & $\mathrm{X}$ & & $\mathrm{X}$ & $x$ & & $\mathrm{X}$ & $\mathrm{X}$ & & $\mathrm{X}$ & $\mathrm{X}$ & & \\
\hline 6 & $\mathrm{X}$ & $\mathrm{X}$ & & $\mathrm{X}$ & $\mathrm{X}$ & $\mathrm{X}$ & $\mathrm{X}$ & & & & $\mathrm{X}$ & \\
\hline 7 & $\mathrm{X}$ & & & $\mathrm{X}$ & $\mathrm{X}$ & & & $\mathrm{X}$ & $\mathrm{X}$ & $\mathrm{X}$ & & \\
\hline 10 & $\mathrm{X}$ & & $\mathrm{X}$ & $\mathrm{X}$ & $\mathrm{X}$ & $\mathrm{X}$ & $\mathrm{X}$ & & $\mathrm{X}$ & & & \\
\hline
\end{tabular}




\begin{tabular}{|c|c|c|c|c|c|c|c|c|c|c|c|c|}
\hline 12 & $\mathrm{X}$ & & & $\mathrm{X}$ & & $\mathrm{X}$ & $\mathrm{X}$ & & $\mathrm{X}$ & & & \\
\hline 13 & $\mathrm{X}$ & $\mathrm{X}$ & $\mathrm{X}$ & $\mathrm{X}$ & & $\mathrm{X}$ & $\mathrm{X}$ & $\mathrm{X}$ & & $\mathrm{X}$ & & \\
\hline 14 & $\mathrm{X}$ & & $\mathrm{X}$ & $\mathrm{X}$ & $\mathrm{X}$ & $\mathrm{X}$ & $\mathrm{X}$ & & $\mathrm{X}$ & $\mathrm{X}$ & & \\
\hline 16 & $\mathrm{X}$ & $\mathrm{X}$ & $\mathrm{X}$ & $\mathrm{X}$ & & & $\mathrm{X}$ & & & & & $\mathrm{X}$ \\
\hline 17 & $\mathrm{X}$ & & & $\mathrm{X}$ & $\mathrm{X}$ & $\mathrm{X}$ & $\mathrm{X}$ & $\mathrm{X}$ & $\mathrm{X}$ & $\mathrm{X}$ & & \\
\hline 18 & $\mathrm{X}$ & & $\mathrm{X}$ & $\mathrm{X}$ & $\mathrm{X}$ & $\mathrm{X}$ & $\mathrm{X}$ & & & & $\mathrm{X}$ & $\mathrm{X}$ \\
\hline 19 & $\mathrm{X}$ & $\mathrm{X}$ & $\mathrm{X}$ & $\mathrm{X}$ & $\mathrm{X}$ & $\mathrm{X}$ & $\mathrm{X}$ & & . & & $\mathrm{X}$ & $\mathrm{X}$ \\
\hline 20 & $\mathrm{x}$ & & $\mathrm{x}$ & $\mathrm{X}$ & $\mathrm{X}$ & $\mathrm{X}$ & & $\mathrm{X}$ & $\mathrm{x}$ & $\mathrm{x}$ & & \\
\hline 23 & $\mathrm{X}$ & $\mathrm{X}$ & $\mathrm{X}$ & $\mathrm{X}$ & $\mathrm{X}$ & $\mathrm{X}$ & $\mathrm{X}$ & & $X$ & & & \\
\hline 25 & $\mathrm{X}$ & $\mathrm{X}$ & & & $\mathrm{X}$ & $\mathrm{X}$ & $\mathrm{X}$ & $\mathrm{X}$ & $\mathrm{X}$ & $\mathrm{X}$ & $\mathrm{x}$ & \\
\hline 26 & $\mathrm{X}$ & & $\mathrm{X}$ & $\mathrm{X}$ & $\mathrm{X}$ & & $\mathrm{X}$ & $\mathrm{X}$ & 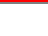 & $\mathrm{X}$ & & \\
\hline 28 & $\mathrm{X}$ & $\mathrm{X}$ & & & $\mathrm{X}$ & & & & $\mathrm{X}$ & & & \\
\hline & \multicolumn{12}{|c|}{ Private equity } \\
\hline 4 & $\mathrm{x}$ & $\mathrm{x}$ & & & & $\mathrm{x}$ & $\mathrm{x}$ & & $\mathrm{x}$ & $\mathrm{X}$ & $\mathrm{x}$ & $\mathrm{X}$ \\
\hline 25 & $\mathrm{X}$ & $\mathrm{X}$ & & & $\mathrm{X}$ & $\mathrm{X}$ & $\mathrm{X}$ & $\mathrm{X}$ & $\mathrm{X}$ & & $\mathrm{x}$ & \\
\hline
\end{tabular}

Note: Red indicates a positive effect, grey indicates no effect, and green denotes a negative effect. 


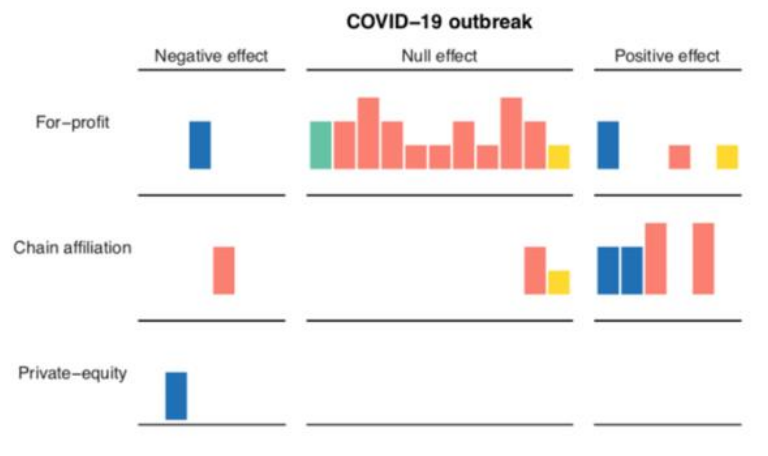

Personal Protective Equipment Negative effect Null effect Positive effect

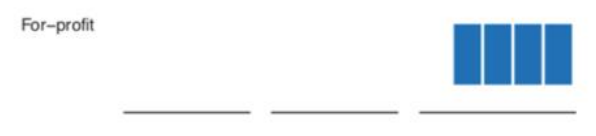

Chain affiliation

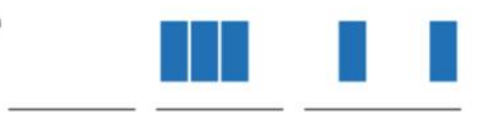

Private-equity

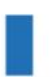

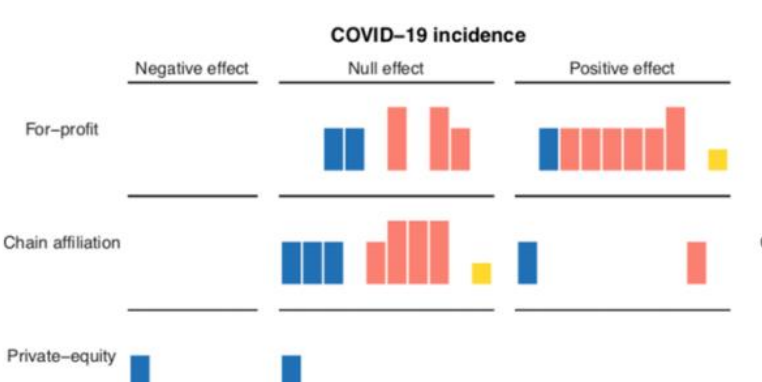

1

Staffing shortage

Negative effect Null effect Positive effect

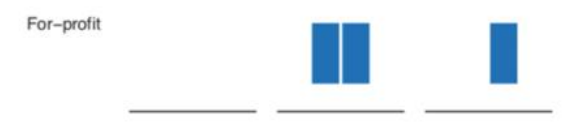

Chain affiliation

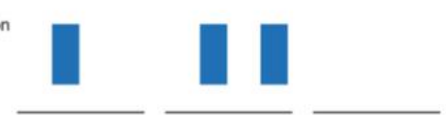

$\underline{\text { Negative effect }} \begin{gathered}\text { COVID-19 mortality } \\ \text { Null effect }\end{gathered}$ For-profit

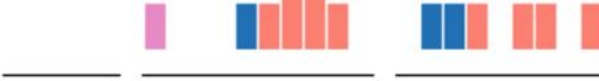

Chain affliation | || || | || || ||

Private-equity

II

Figure A1: Harvest plot on the direction of effect across ownership, risk of bias, and data source. Bar height indicates overall risk of bias and colour denotes data source context. Positive and negative effects are understood as associations in either directions that are statistically significant at the 5\% level. Note that positive effects refer to elevated COVID-19 outcome values. Null effect is understood as differences that are not statistically significant at the 5\% level. Outbreaks usually refer to the presence of any COVID-19 infections, except for one study that defined outbreaks as at least two cases ${ }^{1}$. COVID-19 incidence usually refers to the cumulative number of COVID-19 infections, but also includes binary outcomes on large outbreaks (e.g. ${ }^{17,26}$ ). COVID-19 mortality usually refers to cumulative cases, except for one study which used a binary indicator of at least 6 deaths ${ }^{12}$, and another which analysed a dichotomised outcome of any number of deaths vs no deaths ${ }^{28}$. CQC: Care Quality Commission. 


\section{References}

1. Bui DP, See MD I, Hesse MD EM, et al. Association Between CMS Quality Ratings and COVID-19 Outbreaks in Nursing Homes - West Virginia, March 17-June 11, 2020. Atlanta: U.S. Center for Disease Control; 2020.

https://www.cdc.gov/mmwr/volumes/69/wr/mm6937a5.htm.

2. Chatterjee P, Kelly S, Qi M, Werner RM. Characteristics and Quality of US Nursing Homes Reporting Cases of Coronavirus Disease 2019 (COVID-19). JAMA Netw open. 2020;3(7):e2016930. doi:10.1001/jamanetworkopen.2020.16930

3. Abrams HR, Loomer L, Gandhi A, Grabowski DC. Characteristics of U.S. Nursing Homes with COVID-19 Cases. J Am Geriatr Soc. June 2020. doi:http://dx.doi.org/10.1111/jgs.16661

4. Braun RT, Yun H, Casalino LP, et al. Comparative Performance of Private Equity-Owned US Nursing Homes During the COVID19 Pandemic. JAMA Netw open. 2020;3(10):e2026702. doi:10.1001/jamanetworkopen.2020.26702

5. Li Y, Temkin-Greener H, Gao S, Cai X. COVID-19 infections and deaths among Connecticut nursing home residents: facility correlates. J Am Geriatr Soc. June 2020. doi:http://dx.doi.org/10.1111/jgs.16689

6. Li Y, Fang F, He M. Exploring the N95 and Surgical Mask Supply in U.S. Nursing Homes During COVID-19.J Appl Gerontol. 2020:733464820969015. doi:10.1177/0733464820969015

7. Stall NM, Jones A, Brown KA, Rochon PA, Costa AP. For-profit long-term care homes and the risk of COVID-19 outbreaks and resident deaths. Cmaj. 2020;192(33):E946-E955. doi:10.1503/cmaj.201197

8. He M, Li Y, Fang F. Is There a Link between Nursing Home Reported Quality and COVID-19 Cases? Evidence from California Skilled Nursing Facilities. J Am Med Dir Assoc. 2020;21(7):905-908. doi:10.1016/j.jamda.2020.06.016

9. Sugg MM, Spaulding TJ, Lane SJ, et al. Mapping community-level determinants of COVID-19 transmission in nursing homes: A multi-scale approach. Sci Total Environ. 2021;752:141946. doi:10.1016/j.scitotenv.2020.141946

10. Dean A, Venkataramani A, Kimmel S. Mortality Rates From COVID-19 Are Lower In Unionized Nursing Homes. Health Aff. 2020:10.1377/hlthaff. doi:10.1377/hlthaff.2020.01011

11. Harrington C, Ross L, Chapman S, Halifax E, Spurlock B, Debra B. Nurse Staffing and Coronavirus Infections in California Nursing Homes. Policy Polit Nurs Pract. 2020;21(3):174-186. doi:http://dx.doi.org/10.1177/1527154420938707

12. Unruh MA, Yun H, Zhang Y, Braun RT, Jung HY. Nursing Home Characteristics Associated With COVID-19 Deaths in Connecticut, New Jersey, and New York. J Am Med Dir Assoc. 2020;21 (7):1001-1003. doi:10.1016/j.jamda.2020.06.019

13. Bowblis J, Applebaum R. Prevalence of COVID-19 in Ohio Nursing Homes: What's Quality Got to Do with It? J Aging Soc Policy. 2020;00(00):1-17. doi:10.1080/08959420.2020.1824542

14. Li Y, Cen X, Cai X, Temkin-Greener H. Racial and Ethnic Disparities in COVID-19 Infections and Deaths Across U.S. Nursing Homes. J Am Geriatr Soc. 2020:1-8. doi:10.1111/jgs.16847

15. Fisman DN, Bogoch I, Lapointe-Shaw L, McCready J, Tuite AR. Risk Factors Associated With Mortality Among Residents With Coronavirus Disease 2019 (COVID-19) in Long-term Care Facilities in Ontario, Canada. JAMA Netw open. 2020;3(7):e2015957. doi:10.1001/jamanetworkopen.2020.15957

16. Xu H, Intrator O, Bowblis JR. Shortages of Staff in Nursing Homes During the COVID-19 Pandemic: What are the Driving 
Factors? J Am Med Dir Assoc. 2020;21(10):1371-1377. doi:10.1016/j.jamda.2020.08.002

17. Gorges RJ, Konetzka RT. Staffing Levels and COVID-19 Cases and Outbreaks in U.S. Nursing Homes. J Am Geriatr Soc. $2020: 1-5$. doi:10.1111/jgs.16787

18. McGarry BE, Grabowski DC, Barnett ML. Severe Staffing And Personal Protective Equipment Shortages Faced By Nursing Homes During The COVID-19 Pandemic. Health Aff. 2020;39(10):1812-1821,1821A-1821I. doi:http://dx.doi.org/10.1377/hlthaff.2020.01269

19. Gibson DM, Greene J. State Actions and Shortages of Personal Protective Equipment and Staff in U.S. Nursing Homes. $J A m$ Geriatr Soc. 2020:1-6. doi:10.1111/igs.16883

20. Rowan P, Rebecca Lester P, Michael Levere B, Libersky J, Debra Lipson M, Julie Robison M. A Study of the COVID-19 Outbreak and Response in Connecticut Long-Term Care Facilities Interim Report.; 2020.

21. Brown K, Jones A, Daneman N, et al. Association Between Nursing Home Crowding and COVID-19 Infection and Mortality in Ontario, Canada. Jama Intern Med. 2020:1-8. doi:10.1101/2020.06.23.20137729

22. Burton J, Bayne G, Evans C, et al. Evolution and impact of COVID-19 outbreaks in care homes: population analysis in 189 care homes in one geographic region. Lancet Heal Longev. 2020;1(1):e21-e31. doi:10.1101/2020.07.09.20149583

23. Shen K. Relationship between nursing home COVID-19 outbreaks and staff neighborhood characteristics. medRxiv. 2020;3:2020.09.10.20192203.

https://www.medrxiv.org/content/10.1101/2020.09.10.20192203v1\%0Ahttps://www.medrxiv.org/content/10.1101/2020.09.10.2 0192203v1.abstract.

24. Chen MK, Chevalier JA, Long EF. Nursing home staff networks and COVID-19. Proc Natl Acad Sci. 2020;118(1). doi:10.3386/w27608

25. Gandhi A, Song Y, Upadrashta P. Have Private Equity Owned Nursing Homes Fared Worse Under COVID-19? SSRN Electron J. 2020. doi:10.2139/ssrn.3682892

26. Shallcross L, Burke D, Stat OAC, et al. Risk factors associated with SARS-CoV-2 infection and outbreaks in Long Term Care Facilities in England: A national survey. Lancet Heal Longev. February 2021. doi:10.1101/2020.10.02.20205591

27. Rolland Y, Lacoste MH, De Mauleon A, et al. Guidance for the Prevention of the COVID-19 Epidemic in Long-Term Care Facilities: A Short-Term Prospective Study. J Nutr Heal Aging. 2020;24(8):812-816. doi:10.1007/s12603-020-1440-2

28. Morciano M, Stokes JM, Kontopantelis E, Hall I, Turner AJ. Excess mortality for care home residents during the first 23 weeks of the COVID-19 pandemic in England a national cohort study. medRxiv. 2020. https://medrxiv.org/cgi/content/short/2020.11.11.20229815.

29. Gopal R, Han X, Yaraghi N. Compress the curve: A cross-sectional study of variations in COVID-19 infections across California nursing homes. BMJ Open. 2021;11(1). doi:10.1136/bmjopen-2020-042804 
PRISMA 2009 Checklist

\begin{tabular}{|c|c|c|c|}
\hline Section/topic & $\#$ & Checklist item & $\begin{array}{l}\text { Reported on } \\
\text { page \# }\end{array}$ \\
\hline \multicolumn{4}{|l|}{ TITLE } \\
\hline Title & 1 & Identify the report as a systematic review, meta-analysis, or both. & Title \\
\hline \multicolumn{4}{|l|}{ ABSTRACT } \\
\hline Structured summary & 2 & $\begin{array}{l}\text { Provide a structured summary including, as applicable: background; objectives; data sources; study eligibility criteria, participants, and } \\
\text { interventions; study appraisal and synthesis methods; results; limitations; conclusions and implications of key findings; systematic review } \\
\text { registration number. }\end{array}$ & 2 \\
\hline \multicolumn{4}{|l|}{ INTRODUCTION } \\
\hline Rationale & 3 & Describe the rationale for the review in the context of what is already known. & 3 \\
\hline Objectives & 4 & $\begin{array}{l}\text { Provide an explicit statement of questions being addressed with reference to participants, interventions, comparisons, outcomes, and study design } \\
\text { (PICOS). }\end{array}$ & 3 \\
\hline \multicolumn{4}{|l|}{ METHODS } \\
\hline Protocol and registration & 5 & $\begin{array}{l}\text { Indicate if a review protocol exists, if and where it can be accessed (e.g., Web address), and, if available, provide registration information including } \\
\text { registration number. }\end{array}$ & 3 \\
\hline Eligibility criteria & 6 & $\begin{array}{l}\text { Specify study characteristics (e.g., PICOS, length of follow-up) and report characteristics (e.g., years considered, language, publication status) } \\
\text { used as criteria for eligibility, giving rationale. }\end{array}$ & $4-5$ \\
\hline Information sources & 7 & $\begin{array}{l}\text { Describe all information sources (e.g., databases with dates of coverage, contact with study authors to identify additional studies) in the search } \\
\text { and date last searched. }\end{array}$ & 5 \\
\hline Search & 8 & Present full electronic search strategy for at least one database, including any limits used, such that it could be repeated. & $\begin{array}{l}\text { Supplementary } \\
\text { material }\end{array}$ \\
\hline Study selection & 9 & State the process for selecting studies (i.e., screening, eligibility, included in systematic review, and, if applicable, included in the meta-analysis). & $4-5$ \\
\hline Data collection process & 10 & $\begin{array}{l}\text { Describe method of data extraction from reports (e.g., piloted forms, independently, in duplicate) and any processes for obtaining and confirming } \\
\text { data from investigators. }\end{array}$ & 5 \\
\hline Data items & 11 & List and define all variables for which data were sought (e.g., PICOS, funding sources) and any assumptions and simplifications made. & 5 \\
\hline Risk of bias in individual studies & 12 & $\begin{array}{l}\text { Describe methods used for assessing risk of bias of individual studies (including specification of whether this was done at the study or outcome } \\
\text { level), and how this information is to be used in any data synthesis. }\end{array}$ & 5 \\
\hline Summary measures & 13 & State the principal summary measures (e.g., risk ratio, difference in means). & NA \\
\hline Synthesis of results & 14 & $\begin{array}{l}\text { Describe the methods of handling data and combining results of studies, if done, including measures of consistency }\left(e . g ., I^{2}\right) \text { for each meta- } \\
\text { analysis. }\end{array}$ & $5-6$ \\
\hline
\end{tabular}




\begin{tabular}{|c|c|c|c|}
\hline Risk of bias across studies & 15 & Specify any assessment of risk of bias that may affect the cumulative evidence (e.g., publication bias, selective reporting within studies). & 5 \\
\hline Additional analyses & 16 & Describe methods of additional analyses (e.g., sensitivity or subgroup analyses, meta-regression), if done, indicating which were pre-specified. & $5-6$ \\
\hline \multicolumn{4}{|l|}{ RESULTS } \\
\hline Study selection & 17 & $\begin{array}{l}\text { Give numbers of studies screened, assessed for eligibility, and included in the review, with reasons for exclusions at each stage, ideally with a flow } \\
\text { diagram. }\end{array}$ & 6-10, Figure 1 \\
\hline Study characteristics & 18 & For each study, present characteristics for which data were extracted (e.g., study size, PICOS, follow-up period) and provide the citations. & Table 1 \\
\hline Risk of bias within studies & 19 & Present data on risk of bias of each study and, if available, any outcome level assessment (see item 12). & Table A3 \\
\hline Results of individual studies & 20 & $\begin{array}{l}\text { For all outcomes considered (benefits or harms), present, for each study: (a) simple summary data for each intervention group (b) effect estimates } \\
\text { and confidence intervals, ideally with a forest plot. }\end{array}$ & Figure 2 \\
\hline Synthesis of results & 21 & Present results of each meta-analysis done, including confidence intervals and measures of consistency. & $\begin{array}{l}\text { Figure 2, } \\
\text { Figure A1, } \\
\text { Table } 2\end{array}$ \\
\hline Risk of bias across studies & 22 & Present results of any assessment of risk of bias across studies (see Item 15). & 10, Table A2 \\
\hline Additional analysis & 23 & Give results of additional analyses, if done (e.g., sensitivity or subgroup analyses, meta-regression [see Item 16]). & 14-15 \\
\hline \multicolumn{4}{|l|}{ DISCUSSION } \\
\hline Summary of evidence & 24 & $\begin{array}{l}\text { Summarize the main findings including the strength of evidence for each main outcome; consider their relevance to key groups (e.g., healthcare } \\
\text { providers, users, and policy makers). }\end{array}$ & 15 \\
\hline Limitations & 25 & $\begin{array}{l}\text { Discuss limitations at study and outcome level (e.g., risk of bias), and at review-level (e.g., incomplete retrieval of identified research, reporting } \\
\text { bias). }\end{array}$ & 16 \\
\hline Conclusions & 26 & Provide a general interpretation of the results in the context of other evidence, and implications for future research. & $15-16$ \\
\hline \multicolumn{4}{|l|}{ FUNDING } \\
\hline Funding & 27 & Describe sources of funding for the systematic review and other support (e.g., supply of data); role of funders for the syste matic review. & 13 \\
\hline
\end{tabular}

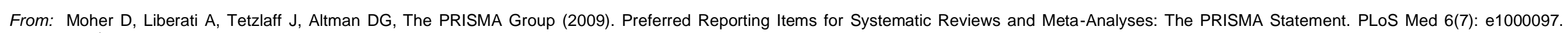
doi:10.1371/journal.pmed1000097

For more information, visit: www.prisma-statement.org.

Page 2 of 2 